\title{
STATUS OF TECHNOLOGY
}

IN THE UNITED STATES FOR SOLIDIFICATION OF HIGHLY RADIOACTIVE LIQUID WASTES

OCTOBER 1968

\section{AEC RESEARCH \& DEVELOPMENT REPORT}

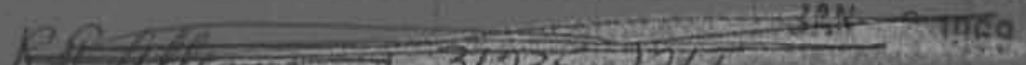

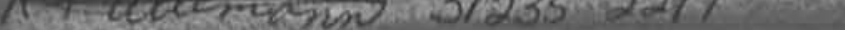
PA Polunewro 30749 325 JoM 1201350 


\section{LEGAL NOTICE}

This report was prepored as an account of Government sponsored work. Neither the United States, nor the Commistion, nor any person acting on behalf of the Commissiont

A. Makes any warranty or representation, expressed or implied, with respect to the accuracy, cam. pleteness, or usefulness of the informotion cortoined in this report, or that the use of any informotion, apparatus, method, or process disetosed in this report may not infringe privately owned rights; or

B. Assumes any liabilities with respect to the use of, or for dantoges resulting from the use of any information, apparatus, method, or process disclosed in this report.

As used in the above, "person octing on behalf of the Commlssion" includes ariy employee or contractor of the Commission or employee of ruch contractor, to the extent that such employee or contractar of the Commission. or employee of such contractar prepares, disseminates, or provides access 10 , any information pursuant to his employment on controct with the Commistion, or his employment with wech contractor

\section{PACIFIC NORTHWEST LABORATORY \\ SICHLNND, WASHINGTOH \\ operated by \\ BATTELLE MEMORIAL INSTITUTE}

for the

UNITED STATES ATOMIC ENERGY COMMISSION UNDER CONTRACT AT(45-1)-1830 
K. J. Schneider

Chemical Technology Department Chemistry and Metallurgy Division

FIRST UNRESTRICTED DCT 31 '0

October 1968 
Printed in the United States of America Available from

Clearinghouse for Federal Scientific and Technical Information National Bureau of Standards, U. S. Department of Commerce Springfield, Virginia 22151

Price: Printed Copy \$3.00; Microfiche $\$ 0.65$ 
STATUS OF TECHNOLOGY IN THE UNITED STATES

FOR SOLIDIFICATION OF HIGHLY RADIOACTIVE LIQUID WASTES

K. J. Schneider

\section{AESTRACT}

The status of technology from research and development in the United States on solidification of highly radioactive wastes from processing of spent power reactor fuels is brought up to date. A summary of individual technology is presented for the four primary processes under development. The four processes are spray solidification, phosphate glass solidification, pot calcination, and fluidized bed calcination. Processes other than these four, including those under development in Europe and in Russia are tabulated. Fully radioactive pilot plant tests have been in progress in the Waste Solidification Engineering Prototypes (WSEP) for the spray, phosphate glass, and pot solidification processes since November 1966. Large scale demonstrations with intermediate level wastes have been underway at the Waste Calcining Facility (WCF) using the fluidized bed calcination process since December 1963. Since start of major research and development 13 years ago, technology has progressed to the point that commercial application for small Purex fuel processing plants (approximately one tonne/day of fuel) is available immediately for the pot calcination process, and should be available for the other three processes in about one year. Technology for larger plants will be available two to three years after scale-up development (not now in progress) is initiated. Technical incentives for solidification of highly radioactive wastes before ultimate storage are presented, and characteristics of the various solidified waste products are summarized. 


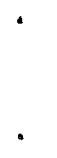

•.

.

$=$

' 


\section{CONTENTS}

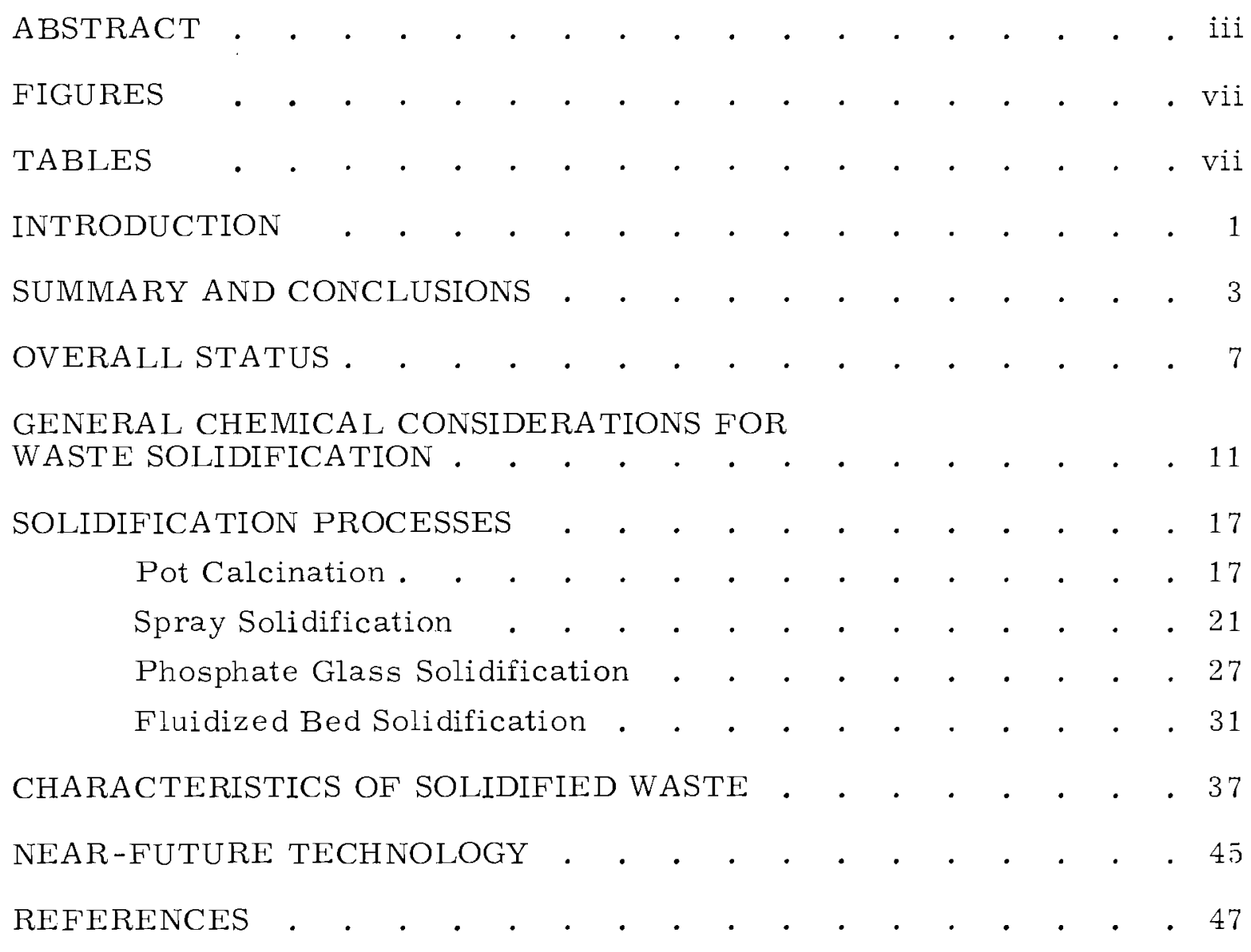





\section{FIGURES}

1 Primary Solidification Techniques in the United States

2 Effects on Heat Removal from Solidified Waste Pots

\section{TABLES}

I Summary of Research and Development on Solidification of High-Level Waste

II Range of Chemical Compositions of High-Level Liquid Waste

III Time Cycles and Capacities for Pot Calcination

IV Characteristics of Solidified High-Level Waste 


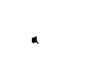

,

. 


\title{
STATUS OF TECHNOLOGY IN THE UNITED STATES \\ FOR SOLIDIFICATION OF HIGHLY RADIOACTIVE LIQUID WASTES
}

\author{
K. J. Schneider
}

\section{INTRODUCTION}

The conversion of high-level liquid wastes to solids as a pretreatment for storage is being developed in laboratories of nearly all countries with significant near-future nuclear energy. Solidification is being developed so widely because it is the only reasonably attainable technique for achieving a substantial increase in the safety associated with the storing and disposal of the high-level waste from the nuclear power industry. Other techniques, more exotic and perhaps more positive (such as transporting wastes to other planets or to stars, or "neutralizing" the radioactivity by nuclear physics) are certainly not attainable in the immediate future.

It is expected that solidification will provide orders of magnitude more safety than liquid storage in the handling of high-level wastes. This increased safety is because wastes stored in the solid form are:

(1) Immobile,

(2) Less soluble in water,

(3) Considerably smaller in volume, and

(4) More rugged physically than those stored as liquids.

For material that must be stored for many years or transported over private property, these advantages are significant and real.

It must be recognized however, that solidification is only part of the total disposal scheme. The other part is storage virtually forever* under stable, controlled conditions. Although guidelines for such storage are very important to the problem, they have not yet been established on a national or world-wide basis.

\footnotetext{
* For wastes containing $0.1 \%$ of the ${ }^{239} \mathrm{Pu}$ in 1 tonne of fuel from a thermal reactor with exposure history of 45,000 MWd/tonne @ $30 \mathrm{MW} /$ tonne and aged 300 years, approximately 10 million permissible human body burdens each of $239 \mathrm{Pu}$ and $90 \mathrm{Sr}$ (two of the more toxic radioactive constituents) remain. (1) The content of plutonium is reduced by only a factor of two in the next 24,000 years.
} 
The requirements of protection from the high toxicity and high intensity of nuclear radiation for storage of high-level wastes, whether solid or liquid, are grossly complicated by the requirement of removing the large amounts of heat of radioactive decay. The heat content of waste is sufficient to require positive cooling (and in many cases, forced cooling) of the wastes for years.

A considerable amount of work has been conducted in the past 13 years, and is in progress presently, for the development of solidification techniques for high-level liquid wastes. Four processes for solidification of high-level liquid wastes have been developed in the USA to the point of radioactive demonstration on an engineering scale. The four processes are pot calcination, spray solidification, phosphate glass solidification, and fluidized bed calcination.

Eventually, more advanced techniques may provide a true ultimate solution to the problem of disposal of high-level radioactive wastes. However, the lack of a true ultimate solution in no way lessens the need for the the development and industrial application of techniques which will provide a marked increase in safety. 


\section{SUMMARY AND CONCLUSIONS}

The only practical method known and under development today for improved safety in storage of high-level nuclear wastes is pretreatment by conversion of the wastes to immobile solids. Development of solidification of high activity level liquid wastes in the USA has been narrowed from many processes to the four most promising: pot calcination, spray solidification, phosphate glass solidification, and fluidized bed calcination. The technology has progressed to the point that the pot, spray, and phosphate glass processes are being demonstrated with full-activity-level wastes in engineering-scale equipment, and the fluidized bed process has been demonstrated with intermediate-activity-level wastes in large-scale equipment for nearly five years. Most of the basic technology has been obtained; nonradioactive development work is nearly completed and radioactive tests are in progress.

In about two years, development of solidification processes for wastes from power reactor fuels supported by the AEC is expected to be reduced. At that time, full level demonstrations on the pot, spray, and phosphate glass solidification processes and their supporting studies will have been completed; operation of the fluidized bed calcination process will continue on intermediate-activity-level wastes. During the following two to three years, development will be limited primarily to measurement. and evaluation of characteristics of actual solidified waste, engineering and economic analysis of waste solidification in the total fuel reprocessing scheme, engineering scale-up to sizes larger than about 1 tonne*/day of equivalent fuel, and safety analysis of solid storage versus liquid storage. The results of these latter studies will largely determine the role of solidification of high-level wastes in the fuel processing cycle.

The chemical treatment of high-level wastes required to achieve solidification, certain problems in waste solidification, and the characteristics of the solidified waste are all strongly influenced by the chemicals that get into the waste streams during fuel reprocessing. Consequently, waste solidification will likewise influence the chemical processing used during fuel reprocessing.

* Tonne is a metric ton, $1000 \mathrm{~kg}$ or $2205 \mathrm{lb}$. 
For capacities in the range of waste from 1 tonne/day of fuel (assuming about 400 liters of waste/tonne of fuel), the pot calcination process has been developed to a state of readiness for commercial use, with a minimum of laboratory testing required for a specific application. The spray solidification, phosphate glass soilidification, and fluidized bed solidification processes are approaching readiness for commercial use, with some pilot plant testing currently required for a specific application. (For wastes that are composed mainly of aluminum nitrate, the fluidized bed process is ready for commercial use. Scale-up to capacities greater than high-level waste from 1 tonne/day of fuel on any of the four processes will require further development. In two to three years, all four processes are expected to be at about the same point of development.

Pot calcination is a simple batch process that is adaptable to a wide variety of feed compositions. Its disadvantages are that a stainless steel pot is required, the amount of self-generating heat (from decay of fission products) which can be incorporated into a pot is limited, the capacity of a system must be increased by multiple pot lines, and the solidified waste is quite water soluble.

Spray solidification is a continuous process with very low hold-up volumes; it is adaptable to a moderately wide variety of feed compositions, and produces a variety of good quality solids. Its disadvantages are that it is a moderately complicated system, it requires good flow control of sometimes difficuit-to-handle feed solutions, it requires high quality atomization, and at present it requires the use of a relatively expensive platinum melter. Scale-up to capacities greater than about 30 liters/hr of liquid waste will require additional development.

Phosphate glass solidification is a continuous process that produces a good quality glass product. Its disadvantages are that is is a moderately complicated system, it requires operation with slurries that are difficult to handle, it cannot retain sulfate in the final solid, and at present it requires the use of a relativeiy expensive platinum melter. Scale-up of the melter to capacities greater than about 30 liters/hr of liquid waste wili require additional development. 
Fluidized bed calcination is a continuous process with a relatively high ratio of capacity-to-size. Its granular solidified waste is readily transportable by pneumatic means and is conducive to storage in large containers. Its disadvantages are that it is a moderately complicated system that requires a complex heating scheme for larger calciners, and it requires a large hold-up of solidified waste. Because the fluidized bed system is very amenable to scale-up, little additional development would be needed for high capacity systems.

The degree of retrievability of the solidified waste-can package in its final disposal system may well affect the choice of process or solidified waste product selected for any specific application. In general, the more readily retrievable the package, the more control we have over the integrity of the package for the long time of concern (hundreds of thousands of years). Thus, the ultimate safety of a package that is readily retrievable but has potentially questionable storage characteristics may be comparable to a poorly retrievable package with very good longterm storage characteristics.

Solidification has not been used in commercial fuel reprocessing primarily because commercial fuel reprocessing is not yet a sufficiently major business to create an important need for solidification, because the reliability and flexibility of solidification processes have not yet been thorcughly demonstrated, and because the safety aspects of solidification and long-term storage have not been economically quantified. In the next three to five years, all of these conditions will have been changed, and the course of waste solidification will have been determined. 


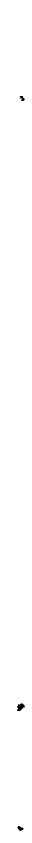




\section{OVERALL STATUS}

The four solidification processes developed to the point of radioactive demonstration on an engineering scale in the USA are shown in Figures 1a, 1b, 1c, and 1d. They are the pot, spray, phosphate glass, and fluidized bed processes, respectively. The pot, spray, and phosphate glass processes have been demonstrated for the AEC on a full-ievel, engineering scale in the Waste Solidification Engineering Prototypes (WSEP) by Battelle-Northwest at Richland, Washington, since November 1966. Demonstration will be completed in 1970. The fluidized bed process has been demonstrated for the AEC in a large capacity plant in the Waste Calcining Facility (WCF) by Idaho Nuclear Corporation at Idaho Falls, Idaho, operating on intermediate-level feeds since 1963.

The pot, spray, and phosphate glass processes have been developed and demonstrated at processing rates of 10 to 20 liters/hr of liquid waste, or waste from about 1 tonne/day of nuclear fuel. The fluidized bed process has been demonstrated at high rates of 230 liters/hr of intermediate-level liquid waste which contains very low amounts of self-heat-generating constituents. Scale-up of all processes beyond about 1 tonne/day equivalent fuel will require some additional nonradioactive development. An overall summary of the status of development of these and several other processes is described in Table I。

Other processes have been developed to a lesser degree in this country, but discussion will be limited to the four processes with the furthest development, since these four processes encompass most features of ail process developments. In all processes, heat is applied to raise the temperature of the waste to 400 to $1200^{\circ} \mathrm{C}$. At these temperatures, essentialiy all the volatile constituents (primarily water and nitrates) are driven off, leaving a solid or a melt that will cool to a solid. The final solid has, therefore, been exposed to a high temperature environment, which is, in effect, an accelerated aging process. Because of this pre-aging process, and because chemical reactions are generally quite slow in the solid phase at these temperatures, the resulting solids are relatively stable chemically, at temperatures lower than thoseduring processing. 


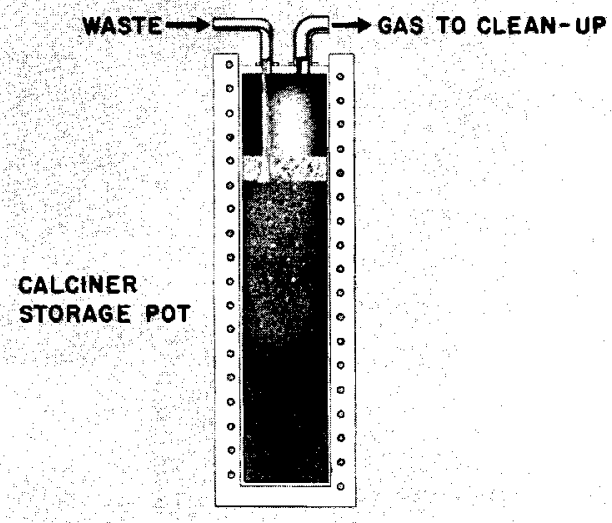

Neg 0681696-4

a. Pot Solidification

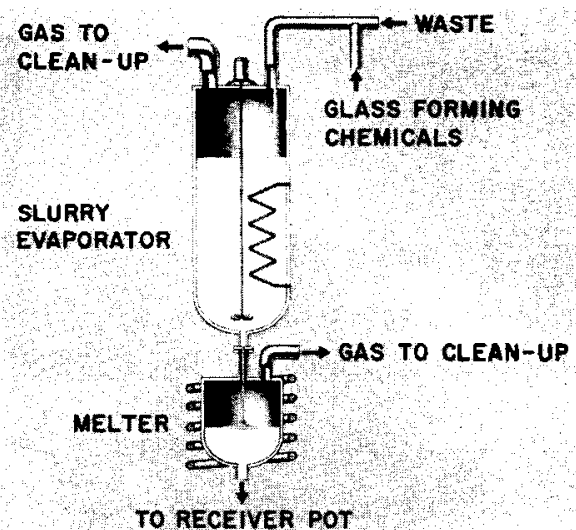

Neg $0681696-1$

c. Phosphate Glass Solidification

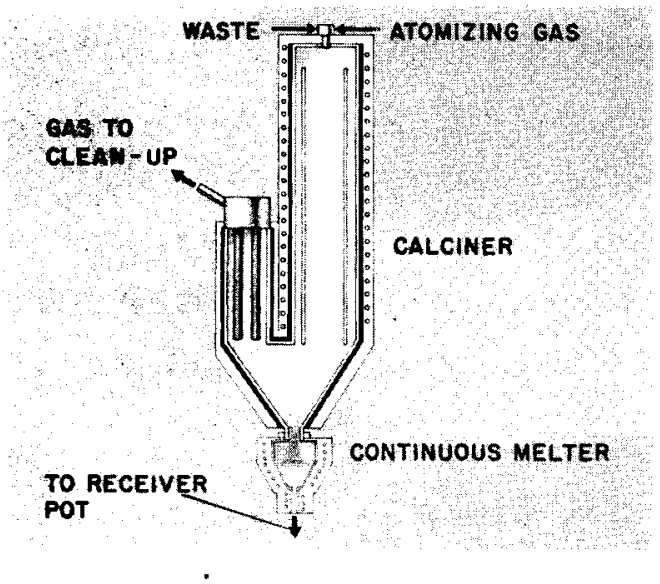

Neg 0681696-3

b. Spray Solidification

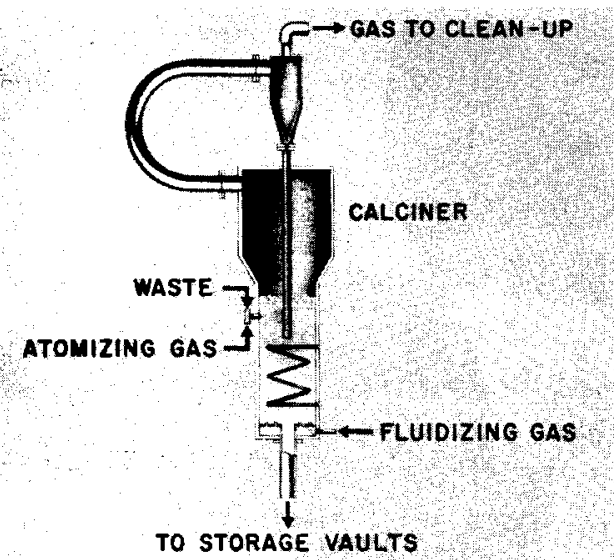

Neg $0681696-2$

d. Fluidized Bed Solidification

FIGURE 1. Primary Solidification Techniques in the United States 
TABLE I. Summary of Research and Development on Solidification of High-Level Waste ${ }^{\text {(a) }}$

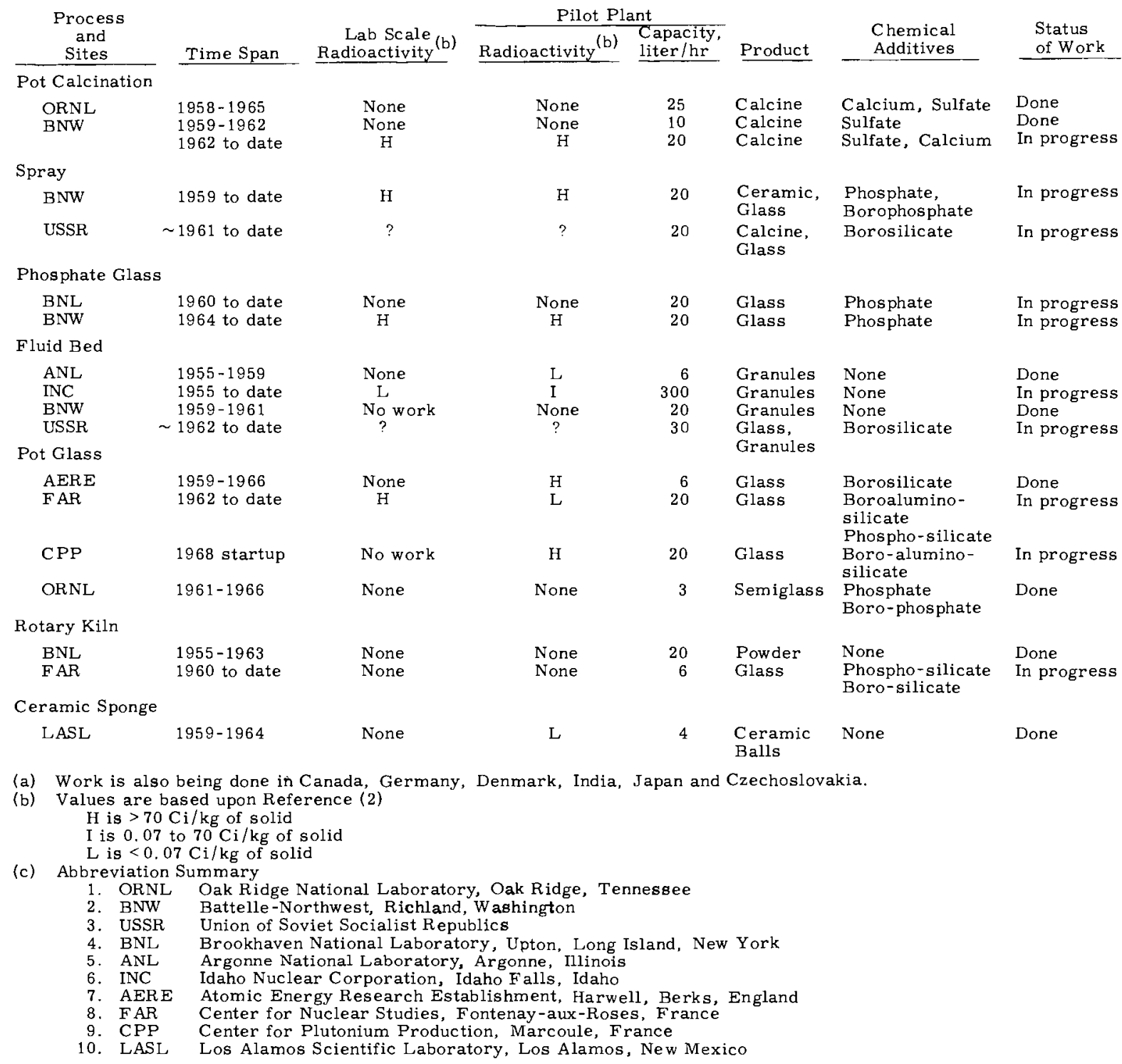




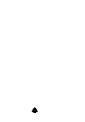


GENERAL CHEMICAL CONSIDERATIONS FOR WASTE SOLIDIFICATION

Solvent extraction using nitric acid or nitrate salts is the only production-scale means currently used for the first stage removal of fission products from the fissionable material in spent nuclear fuel. Consequently, ali high-level wastes are primarily aqueous solutions of inorganic nitrate salts (which will decompose at temperatures below $500{ }^{\circ} \mathrm{C}$ ). Differences in wastes occur mainly in the amount and type of salts added to the solutions during reprocessing of the spent reactor fuel. The amount of these artificially added chemicals can vary from being predominant to being mere impurities when compared to the chemical fission product content of the wastes. The variations usually have marked impact on the solidification process conditions and on the nature of the final solidified waste. Consequently, solidification of wastes will have a definite influence on reprocessing conditions wherein the wastes are formed.

All processes for solidification of high-level waste generate additional waste streams that contain intermediate levels of radioactivity. These are the vapor or condensate streams from the solidifier that have been decontaminated by factors of 50 to 1000. From this point, decontamination requirements of the effluents are comparable to those from the high-level liquid waste handling system of the fuel reprocessing plant. (This is a separate subject and is beyond the scope of this report.) If solidification is included in the chemical reprocessing plant, processing of these vapor streams would logically and readily be done by recycle routing to the existing high-level liquid waste concentration and processing equipment. Only a modest increase in capacity (on the order of 10\%) of the liquid waste processing capacity of the reprocessing plant would be required. If a solidification plant was located remote from the fuel. reprocessing plant, the solidification plant would need a complete smaller capacity version of similar intermediate-level waste treatment facilities. In addition, shipment of the high-level liquid waste to the solidification plant and shipment of recovered nitric acid with low-to-intermediate-level radioactivity content back to the separations plant would be required. 
Therefore, considerable economic and safety incentives exist for integration of solidification plants with the primary reprocessing plant.

Table II describes five waste compositions which bracket the ranges of chemical compositions of wastes expected from fuel reprocessing by solvent extraction. All compositions are shown at a volume of 378 liters/ tonne of uranium fuel (100 gal/tonne) to provide a common basis, although concentrations greater than about $4 \underline{\mathrm{N}}$ in total metallic ions will generally result in excessive precipitation which is unmanageable for extended storage. $(3,4,5)$ The compositions shown in Table II assume the fuel cladding is not dissolved with the fuel; consequently, the fuel cladding constituents are not present in the high-level waste.

Waste composition number 1 is typified by a very high content of iron and low content of other constituents. This waste has been generated by one reprocessor ${ }^{(6)}$ by dissolving an iron fuel container with the fuel. Composition number 2 is a moderately "dirty" waste from first cycle waste combined with second cycle waste that contains sulfate (which comes from a reductant in the uranium-plutonium partitioning step). Waste number 3 is the same as waste number 2 that has been neutralized before storage. Waste number 4 is a "clean" waste which would come from the first solvent extraction cycle with reasonable care in maintaining a flowsheet reasonably free of nonradioactive chemicals. This is expected to be a fairly typical waste in the near future. Waste number 5 is one generated in a TBP-25 process where aluminum nitrate is used for the salting agent in the solvent extraction process.

Acidification of waste number 3 is required before solidification, since direct calcination will form unstable, hygroscopic $\mathrm{Na}_{2} \mathrm{O}$. Upon acidification, this waste then approaches that of waste number 2. Processing with the TBP -25 process offers no known major advantages over the Purex process, so waste number 5 is believed to have only minor importance in the future. Consequently, wastes 1, 2 and 4 bracket the range of expected high-ievel liquid waste compositions. 
TABLE II. Range of Chemical Compositions of High-Level Liquid Waste

\begin{tabular}{|c|c|c|c|c|c|}
\hline \multirow[b]{2}{*}{ Constituent } & \multicolumn{5}{|c|}{ Concentration, Molarity@378 liters/tonne ${ }^{(a)}$} \\
\hline & No. 1 & No. 2 & No. 3 & No. 4 & No. 5 \\
\hline \multicolumn{6}{|c|}{ General Chemical Composition of Inert Materials } \\
\hline $\mathrm{Na}$ & low & high & high & low & low \\
\hline $\mathrm{Fe}$ & high & med & med & low & low \\
\hline Al & 0 & 0 & 0 & 0 & high \\
\hline $\mathrm{SO}_{4}$ & 0 & high & high & 0 & \\
\hline
\end{tabular}

Actual Chemical Composition of Inert Materials

\begin{tabular}{|c|c|c|c|c|c|}
\hline $\mathrm{H}$ & 3.7 & 3.93 & $(-) 0.01$ & 6.29 & 4.25 \\
\hline $\mathrm{Fe}$ & 0.93 & 0.445 & 0.445 & 0.05 & 0.05 \\
\hline $\mathrm{Cr}$ & 0.012 & 0.024 & 0.024 & 0.012 & 0.012 \\
\hline $\mathrm{Ni}$ & 0.005 & 0.010 & 0.010 & 0.008 & 0.008 \\
\hline $\mathrm{A} 1$ & 0.001 & 0.001 & 0.001 & 0.001 & 0.65 \\
\hline $\mathrm{Na}$ & 0.138 & 0.93 & 3.67 & 0.10 & 0.10 \\
\hline $\mathrm{U}$ & 0.010 & 0.010 & 0.010 & 0.010 & 0.010 \\
\hline $\mathrm{Hg}$ & $<0.001$ & $<0.001$ & $<0.001$ & $<0.001$ & $<0.001$ \\
\hline $\mathrm{NO}_{3}$ & 7.5 & 5.37 & 2.0 & 6.66 & 6.5 \\
\hline $\mathrm{SO}_{4}^{3}$ & -- & 0.87 & 0.87 & -- & -- \\
\hline $\mathrm{PO}_{4}^{4}$ & 0.003 & 0.006 & 0.006 & 0.003 & 0.003 \\
\hline $\mathrm{SiO}_{3}$ & 0.010 & 0.010 & 0.010 & 0.010 & 0.010 \\
\hline$\underline{F \quad 3}(b)$ & $<0.001$ & $<0.001$ & $<0.001$ & $<0.001$ & $<0.001$ \\
\hline$\sum \mathrm{M}_{\text {chem }}$ & 3.03 & 2. 48 & 5.22 & 0.365 & 2.31 \\
\hline $\begin{array}{l}\text { kg oxide / } \\
\text { tonne }\end{array}$ & 31.7 & $28.1^{(c)}$ & $60^{(c)}$ & 4. 6 & 17.2 \\
\hline
\end{tabular}

Chemical Composition of Major Materials from Nuclear Fission

Fuel Exposure in Thermal Reactors

$\begin{array}{lll}\mathrm{Mo} & 0.065 & 0.130 \\ \mathrm{Tc} & 0.014 & 0.031 \\ \mathrm{Sr} & 0.0155 & 0.036 \\ \mathrm{Ba} & 0.0195 & 0.041 \\ \mathrm{Cs} & 0.035 & 0.078 \\ \mathrm{Rb}{ }_{\mathrm{Y}+\mathrm{RE}^{(\mathrm{d})}} & 0.007 & 0.014 \\ \mathrm{Zr} & 0.12 & 0.274 \\ \mathrm{Ru} & 0.065 & 0.143 \\ \mathrm{Rh} & 0.032 & 0.082 \\ \mathrm{Pd} & 0.0074 & 0.013 \\ \mathrm{Ag} & 0.017 & 0.043 \\ \mathrm{Cd} & 0.0008 & 0.0016 \\ \mathrm{Te}{ }^{(b)} & 0.0008 & 0.0025 \\ \sum_{\mathrm{Mp}}^{+} & 0.0064 & 0.014 \\ \mathrm{~kg} \mathrm{oxide/tonne} & 0.91 & 1.73\end{array}$

(a) Tonne is a metric tonne, $1000 \mathrm{~kg}$ or $2205 \mathrm{lb}$.

(b) $\mathrm{M}^{+}$is metal equivalents, or normality of metal ions (does not include acid).

(c) Does not include the sulfate. If sulfate is not volatilized, approximately $27 \mathrm{~kg} /$ tonne of additional oxides are formed.

(d) RE is rare earth elements. 
The second part of Table II shows the amount of major chemical materials resulting from fissioning in thermal reactors with moderate and high exposure histories. The 20,000 MWd/tonne exposure is typical of current reactors, and the 45,000 MWd/tonne represents probable maximum exposures in future thermal reactors. (7) It is obvious that the chemical content of fission products is significant in all possible combinations of power reactors and fuel reprocessing schemes. In fact, with only moderate attempts to minimize the inert contaminants in the waste, the chemical equivalents of fission products will exceed those of the inert contaminants, and the chemistry of the fission products will be the controlling factor in the waste treatment steps.

Another point of interest is that the absolute minimum volume of solidified waste (that of fission product oxides alone) is about 1. 1 liters/1000 MWd thermal exposure (assuming the density of the solids is $1.0 \mathrm{~g} / \mathrm{ml}$ ). Contributions from inert chemicals in the compositions shown in Table II can increase that volume by a factor up to 4. Additional chemical additives are often needed to perform chemical functions during solidification. These additives are based on the total composition of chemicals present, and can increase the waste volumes by as much as an additional factor of 2 .

Solidification processes that form melts require significant chemical modification of almost any waste composition. Compositions for waste solidification generally require at least 70 mole $\%$ of inert chemicals to incorporate the fission products into materials that are meltable at reasonably low temperatures, or less than about $1000{ }^{\circ} \mathrm{C}$. (A more typical value for inert chemical content in melts is $85 \%$, Melts have been developed in which the major melt-making fluxes are phosphates, $(8,9,10)$ borophosphates, $(11,12,13)$ silicates, ${ }^{(14,15)}$ borosilicates, $(11,14,15)$ and borates. (16) In most cases, potentially workable chemical composition ranges have been defined. However, because of the complex interaction of all the constituents in the wastes, in no case has a general correlation for chemical composition been defined. Thus, paper study development of a workable melt composition cannot be done unless the composition is modified 
to one that has been developed. Therefore, each waste composition encountered requires at least laboratory investigation of melt-forming composition before melt solidification can proceed. Similar studies are usually necessary to predict occurrence of special problems, such as ruthenium or sulfate volatility, foaming, stickiness, etc., for all solidification processes.

Three of the inert chemical constituents listed in Table II are sufficiently troublesome in solidification to merit effort to keep them out of high-level wastes. These constituents are sulfate, fluoride, and mercury ions. Sulfate ion is generally unstable chemically at the higher range of temperatures reached in solidification $\left(700^{\circ} \mathrm{C}\right.$ and higher) and tends to volatilize. Retention of sulfate in the solidified waste at temperatures above $700^{\circ} \mathrm{C}$ is difficult and requires chemical additives (usually calcium), and for melts it is nearly impossible above 850 to $900^{\circ} \mathrm{C}$. (8) This volatilization results in added corrosion problems in the off-gas system recycle and increased sulfate concentrations in the liquid waste for cases of partial volatilization, or another medium-to-high-level waste stream that requires special treatment and disposal for cases of complete volatilization. Sulfate also causes severe precipitation and resultant solution handling problems from sodium-rare earth sulfates when present at concentrations of approximately 0.5ㅆ greater。(17)

Fluoride is retained with difficulty (by using calcium) in solidified waste processing up to temperatures of about $600^{\circ} \mathrm{C},(18)$ and is probably impossible to retain significantly at higher temperatures. ${ }^{(19)}$ If it cannot be retained, it must be disposed of by another means such as in the gaseous stream out of the plant stack or in a separate lower-level waste stream. Fluoride content of much more than about $0.001 \underline{M}$ will significantly increase corrosion of stainless steel and titanium (used generally in waste processing systems), although this corrosion can be partly overcome by use of complexing agents (aluminum, zirconium, etc。). 
Mercury cannot be retained in the solidified waste when processed at temperatures above 400 to $500{ }^{\circ} \mathrm{C}$. When volatilized, the mercury and its oxides condense at temperatures of about $350{ }^{\circ} \mathrm{C}$ and provide relatively serious potential plugging problems. A means for pretreating the waste for removal of mercury has been developed in the laboratory.

Ruthenium, one of the ever present fission products, is just as cantankerous in waste solidification as it is in fuel reprocessing. One to eighty percent of the ruthenium will usually oxidize and volatilize during solidification, and it is more difficult to remove from the off-gas stream than the nonvolatile materials. Chemical additions to minimize the oxidizing potential during solidification are sometimes required to minimize oxidation to the volatile $\mathrm{RuO}_{4}$ form. Even then, volatilization of at least $1 \%$ is usually encountered. 


\section{SOLIDIFICATION PROCESSES}

\section{POT CALCINATION}

Pot calcination, which was developed at ORNL, is a batch process that has been developed to a state of readiness for commercial radioactive use. It has been demonstrated on both a laboratory scale and a pilot plant scale with no radioactivity and is presently being demonstrated with full-level radioactivity. Its advantages are that it is a simple process that is adaptable to a wide variety of feed compositions. Its disadvantages are that a stainless steel pot is required, the amount of heat which can be incorporated into a pot is limited, the capacity of a system must be increased by multiple-pot lines, and the solidified waste is quite water soluble. Development requirements for specific application are laboratory tests on actual feed compositions, simplification of pot design to reduce costs of pots, and, possibly, modification of pot geometry to permit higher processing rates and to allow incorporation of solids with higher heat densities.

Pot calcination is a batch process in which the principal processing vessel, the pot, is also the final container for the solidified waste. In pot calcination, liquid waste is added to a pot that is heated in a multiplezone heating and cooling furnace. The waste is concentrated at a constant volume to the point that scale (salt cake) forms on the walls of the pot. As calcination continues, the scale grows in thickness and reduces the capacity for heat transfer from the pot wall to the boiling sludge, and therefore the feed rate must be reduced proportionately. When the feed rate is reduced to an "unprofitable" rate (about 5 liters/hr), the feed is shut off. At this point, the scale has grown inward from the pot wall and upward from the bottom of the pot to fill the pot, except for a thin-cone-shaped liquid-containing void in the upper 2 to 3 feet of the salt cake. Heating is then continued until the liquid is boiled to dryness and all of the waste in the pot has been calcined and has reached the temperature of 850 to $900^{\circ} \mathrm{C}$. The pot is then cooled in the furnace, removed, sealed, and taken to storage. 
The product from pot calcination (i.e., the solidified waste) is a mixture of oxides (and sulfates, if sulfate is present in the waste) of the metallic constituents in the original liquid waste. The product is a porous, friable calcine with a low thermal conductivity and a relatively high solubility in aqueous solutions. Some of the common characteristics of the various kinds of solidified wastes are shown in Table IV.

The basic elements of equipment required for pot calcination are (a) a multiple-zone furnace for heating and cooling the calcine, (b) a pot for calcining the waste, and (c) an off-gas line from the pot to the first process condenser which can be washed down continually. The successful performance of the se pot calcination equipment requirements has been demonstrated using full-level wastes in the Waste Solidification Engineering Prototypes.

A multiple-zoned furnace is required because the heating and cooling needs are different for each vertical portion of the pot at any given time. Some of the sludge and scale formed during calcination and solids from the feed fall to the bottom of the pot; thus, solids accumulation progresses faster from the bottom upward than it progresses from the walls inward. The actual number of furnace zones required is not definitely known, but six zones for a pot to be filled with 6 feet of calcine is definitely adequate and may be superfluous. (21) Maximum furnace heating requirements are based on pot diameter. For 8 - and 12 -inch diameter pots, approximately 35 and 70 kilowatts of net heating capacity are needed, respectively, during the period of maximum boilup rates. Cooling is also required in the furnace to remove the heat of radioactive decay from the calcine after all material has bcen calcined. Zone cooling is required for the same reasons zone reating is needed. Design of furnaces with zone heating is relatively straightforward, while design for zone cooling presents a major problem to the designer. The walls of pots containing $1.5 \mathrm{~kW} /$ linear feet of pot of radioactive decay heat have been cooled to $400^{\circ} \mathrm{C}$, using air indirectly on the outside of a second container surrounding the pot. 
Because the pots serve as the processing vesiels, they are exposed to severe corrosion conditions during calcination and must be made of corrosion-resistant material. Corrosion of 304-L stainless steel is negligible during processing ( $<0.0003$ in. / day). Pots must have liquid level and temperature measurement devices. Liquid level may be measured with either a standard gas-purged dip tube or with an internal temperature sensor near the top of the pot. In demonstration tests, temperature measurements are taken at the centerline and at the pot walls in each zone, with in-place thermoccuples. Because of the significant cost of these thermocouples, an incentive exists in commercial use for reducing the number of thermocouples or for making the thermocouples reusable。

The off-gas line from the calciner must be washed down continuously, if possible, or at least at frequent intervals. If not done, the line would plug with entrained calcine or sludge after as few as two or three runs. Continuous washing by condensing about $10 \%$ of the vapors has been performed successfully in WSEP. (21) Routing this condensate to the same place as the majority of the condensate has also been demonstrated. Occasionally washing the neck of the pot near the end of each batch will also keep the neck of the pot clean.

Internal heat from decay of radioactive constituents requires slight modifications of operating techniques. With the presence of internal heat, cooling of the pot wall is necessary before the material at the center of the pot has reached its final maximum temperature, or the center temperature will exceed that desired. (Higher temperatures result in severe corrosion and potertially undesirable volatility of some constituents.) Control of this temperature has been successfully demonstrated by using a simple 3 -step reduction of furnace temperatures, based on pot wall and center temperatures.

The pot calcination cycle may be divided into three major portions: (a) the period of feeding and concentrating at constant feed rate, (b) the period of pot wall scaling and calcining, causing gradual reduction of feed rates, and $(c)$ the calcining and cooling period when 
feed is turned off and the calcine is heating to 850 to $900{ }^{\circ} \mathrm{C}$, then is cooled in preparation for removing the pot from the furnace. Typical time requirements for each of the steps are summarized in Table III. Since diameter of the pot has a relatively small effect on the overall processing capacity, an increase in capacity must be obtained by changes in pot geometry (e.g., annular pots) or by multiple pot lines.

TABLE III. Time Cycles and Capacities for Pot Calcination ${ }^{(a)(21)}$

Pot Diameter, in.

\begin{tabular}{rr}
8 & 12 \\
6 & 6 \\
60 & 120 \\
500 & 1000 \\
30 & 60 \\
10 & 10 \\
20 & 30 \\
10 & $30(\mathrm{c})$ \\
\hline 40 & 70 \\
12 & 14
\end{tabular}

Overall Cycle Capacity, liters/hr

0.75

0.9

(a) For pots containing $5 \mathrm{~kW}$ internal heat

(b) For feeds relatively free of foaming tendencies

(c) Estimated. Exact data not available.

Longer pots provide a slight increase in capacity because there is no marked increase in calcining and cooling times. Maximum boilup rate is limited by entrainment in the upper part of the pot, or by the crosssectional area of the pot. Some feeds may contain significant amounts of foam-making constituents ( $e_{\circ} g$, dibutyl phosphate from the reprocessing plant). If foaming is present, feed rates during the initial boiling period must be reduced from those shown in Table III.

During pot calcination of Purex wastes, ruthenium is volatilized to the extent of about $5 \%$ and 10 to $30 \%$ for low-sulfate wastes and 
high-sulfate wastes, respectively. by the addition of chemical reductants, such as nitric oxide gas blankets or phosphites.

If sulfate is present in the waste, less than $2 \%$ will be volatilized from the calcine if the chemical composition of the feed is adjusted to assure that the chemical equivalent of alkali or alkaline earth metallic ions is present. In practice, sodium and/or calcium nitrates are usually used.

Volatility of cesium and rubidium, which are always present as fission products, can be virtually eliminated by adding enough sulfate or phosphate ions to the feed to be chemically equivalent to the total amount of alkali metals present.

Entrainment from the pot calciner, when operated on a reasonably conservative basis, is approximately $0.4 \%$ of the total feed.

\section{SPRAY SOLIDIFICATION}

Spray solidification is a continuous process that has been extensively developed and is approaching readiness for commercial use. It has been demonstrated on both a laboratory scale and a pilot plant scale, with no radioactivity and with full level radioactivity. The spray solidification process was developed at Battelle-Northwest. Its advantages are that it is a continuous process with very low hold-up volumes, it is adaptable to a moderately wide variety of feed compositions, and it produces a variety of good quality solids. Its disadvantages are that it is a moderately complicated system, it requires good flow control of sometimes difficult-to-handle feed solutions, its performance requires high quality atomization, and at present it requires the use of a relatively expensive platinum melter. Development requirements for specific applications are cold laboratory and modest cold pilot plant tests on actual feed compositions, and chemical composition investigations to control ruthenium volatility. Current pilot plant testing of melting the calcined powder in the receiver pot, rather than using an expensive platinum melter, may eliminate one of the disadvantages. 
In spray solidification, liquid waste is continuously converted to a dried powder in a spray calciner, the powder is then melted in a continuous melter, and the molten waste is discharged into the receiver and storage pot. In the spray calciner (see Figure $1 \mathrm{~b}$ ), liquid waste (which contains some or all of the melt-making additives) is fed through a pneumatic atomizing nozzle into the top of a heated cylindrical tower. The atomized waste is sequentially evaporated, dried, and calcined to a powder as it falls into a continuous melter below the calciner where it is meited at temperatures of 800 to $1200^{\circ} \mathrm{C}$. Process gases from calcination flow into the adjacent filter chamber, carrying much of the calcined powder as dust. The dust collects on the porous metal filters as the gas passes through. The dust deposits are periodically blown off the filters by sudden pulses of high-pressure steam or air directed backward through the filters by small nozzles. The dislodged dust falls into the melter with the main powder stream. The molten calcine flows through an overflow weir or a freeze valve into the receiver-storage pot below. After the pot is filled, it is cooled in the furnace, sealed, and taken to storage.

The product from spray solidification is a monolithic solid formed after cooling the melt. The solid is a tough, microcrystalline, rock-like material with a fairly good thermal conductivity and a moderately low solubility in aqueous solutions. (Glassy solids have also been made in the spray solidifier, but primary emphasis has been on microcrystalline materials.) See Table IV for some of the common characteristics of spray and other solidified products.

The basic elements of equipment required for spray solidification are (a) an atomizing nozzle and a spray tower for atomizing and dryingcalcining the feed, (b) a multiple-zone furnace for heating the spray tower, (c) an off-gas cleaning system near the spray tower to remove the bulk of the entrained calcine dust from the off-gases, (d) a continuous melter for melting the powdered calcine, (e) a furnace for heating the melter, (f) a pot for receiving the molten waste, and (g) a multiplezoned furnace for heating and cooling the receiver pot. 
The atomizing nozzle must break the feed up into small enough droplets (on the order of 80 to $100 \mu \mathrm{m}$ diameter) to permit dryingcalcining of the feed during its short time (about 10 seconds) in the spray tower. The atomizing nozzle is the heart of the spray calciner, and good atomization is essential. Commercial internal-mixing nozzles, wherein the gas and liquid waste are mixed inside the nozzle below being discharged, perform satisfactorily. External-mixing nozzles, wherein the gas and liquid waste are mixed after discharge from the nozzle, have not provided satisfactory atomization. The use of air is satisfactory for atomization, but superheated steam has not consistently provided adequate atomization. The stainless steel spray tower must provide enough heat transfer area and hold-up to permit drying of the atomized waste (a minimum of about $1 \mathrm{ft}^{2}$ area per liter/hr feed rate and 10 seconds of hold-up time).

The furnace for heating the spray calciner must have multiple zones of heating to temperatures of $800^{\circ} \mathrm{C}$ to provide heat flux which varies slightly with the vertical position of the drier. The top portion of the spray tower (the part above the point where the atomized waste would impinge on the walls of the tower, i. e., 25 to $30 \%$ of the total length of the tower) consumes 35 to $40 \%$ of the heat. The heat requirement for the lower $70 \%$ of the tower is nearly uniform. Approximately 1 kilowatt of net heat for each liter/hr of liquid fuel rate is required.

Because the average particle size of the powdered calcine from a spray calciner is very small (about $50 \mathrm{um}$ diameter), about half of the powder is entrained with the off-gases and must be removed and recombined with the main powder stream. Porous stainless steel filters with an average pore size of $65 \mu \mathrm{m}$ provides adequate cleanup (less than $0.5 \%$ of the dust passes through). Wire-wound filters with $50 \mu \mathrm{m}$ pore size provide similar clean-up after the initial operating period when a pre-coat of calcine dust is deposited. (During this initial pre-coating period up to $5 \%$ of the dust passes through。) Total filter area of about $1 \mathrm{ft}^{2} /$ liter/hr of feed to the calciner is required to keep normal filter pressure drop at a reasonable level of about 
10 inches of water. Periodic pulsed blowback (every 1 to 5 minutes) with air or steam at 20 to $60 \mathrm{lb} / \mathrm{in}^{2}$ pressure through venturis into the filters adequately keeps the filters from accumulating gross amounts of powder.

In the continuous melter, the small amount of residual nitrate and water is driven off from the calcine and the calcine is melted. Platinum is the only reliable metallic material of construction found to date to withstand the environment of corrosion and high temperature. In addition to having a high first cost, platinum has the disadvantage of low radiant emmissivity which requires increased size of melter or increased furnace temperature to obtain a given melting capacity. However, these disadvantages are tolerable. The capacity of a platinum melter that is 10 inches in diameter and has a 14 inch-high heated section is 1.7 liters/hr of melt. (16) Platinum has been used extensively at temperatures up to $1250{ }^{\circ} \mathrm{C}$. A special alloy of $50 \%$ chromium $-50 \%$ nickel is generally satisfactory at temperatures up to $1000^{\circ} \mathrm{C}$, and high chromium/nickel stainless steel and some high-nickel alloys are satisfactory at temperatures up to $900^{\circ} \mathrm{C}$. Discharge of melt from the melter has been adequately demonstrated on a continuous basis using overflow weirs, or batchwise using straight-tube freeze valves wherein a plug of melt about 2 inches long is melted or frozen to provide on-off flow control. Instrumentation has been developed to provide detection of melt level. Foaming or other infrequent off-standard conditions in the melter are detectable by direct viewing through windows into the melter.

The furnace for heating the continuous melter must be capable of providing 3 to 4 kilowatts of heat for each liter/hr of melt formed at furnace temperatures up to $1300^{\circ} \mathrm{C}$. Modifications of standard resistanceheated electrical furnaces or induction-heated furnaces have performed satisfactorily in this service. $(16,24)$

The pot for receiving the molten waste may be made of mild steel if the pot is filled with melt by large, rapid, batchwise dumps from the melter, or if the pot is filled with melts with low melting points (less than about $700^{\circ} \mathrm{C}$ ). This is because the pots must be heated under 
most conditions to the point where the melt will slump to assure complete filling of the pots without formation of stalagmites or voids. (Mild steel pots can acceptably resist temperatures up to about $650{ }^{\circ} \mathrm{C}$ for several-day periods.) Level measurements are required in the pot, and may be accomplished by direct viewing, and approximated by temperature measurement. If discharged to the receiver pot at a slow, continuous rate, molten waste with a melting point above $900^{\circ} \mathrm{C}$ cannot be used to fill a pot because the pot must be maintained at greater than $900{ }^{\circ} \mathrm{C}--$ a temperature range in which oxidation of stainless steel pots by air becomes excessive. Corrosion by phosphate melts on mild steel or stainless steel pots at temperatures about $700^{\circ} \mathrm{C}$ or lower is negligible. $(25,26,27)$

The receiver furnace requirements are similar to those in pot calcination except that total heating requirements depend only upon the natural heat losses from the furnace to maintain the solidified waste at a temperature near its slump or melting point (up to $950^{\circ} \mathrm{C}$ ). Multiple heating zones are required because it is necessary to cool a zone which is full of melt at the same time that a zone which is filling with melt must be heated. Zone heights of 13 inches have proven to be satisfactory in WSEP. Cooling requirements of the pots are similar to those for pot calcination. However, since the thermal conductivity of the spray solidified waste is considerably greater than that from pot calcination, increased heat density is attainable in the product, and proportionally increased cooling capacity is needed (see Table IV).

The spray solidifier concept requires that the sintering point of the calcined feed in the spray tower be higher than the temperature of the walls of the spray tower. Adherence to this limit will prevent gross sticking of calcine to the tower walls. In addition, the melting point of the final powder must be no more than about $900{ }^{\circ} \mathrm{C}$ (see above). The chemical composition of the feed is then adjusted to fit these limitations. Some or all of the melt-making flux can be added as a solid directly to the melter to further widen flowsheet and operational flexibility. 
The capacity of a spray tower increases significantly with (a) wall temperature, (b) degree of atomization, or spray drop size, (c) decreased stickiness of the feed, and (d) length and diameter of the tower. Capacity increases by about $30 \%$ for each $100^{\circ} \mathrm{C}$ increase in wall temperature in the normal operating range of 500 to $750{ }^{\circ} \mathrm{C}$. Atomizing quality can affect capacity by a factor of 2 . Drying capacity when calcining nonmelting calcines is about $30 \%$ less than that with water; capacity for calcining of melting feeds is approximately a factor of 2 lower than with nonmelting calcines. Calcine capacity increases approximately linearly with diameter up to about 2 feet and length up to about 10 feet. Scale-up factors beyond those size limits are not yet well defined. Typical capacity for a melting feed in a spray calciner of the size used in Waste Solidification Engineering Prototypes $^{(21)}$ (13 inches in diameter by 6 feet long) is 20 liters/hr of liquid waste.

The flow sheets most used for spray solidification at Battelle-Northwest produce alkali metal-phosphate solids. These are used primarily because they offer relatively large latitude in chemical composition, they have generally low melting points $\left(700\right.$ to $\left.900^{\circ} \mathrm{C}\right)$, they produce melts with reasonably low viscosities (less than 50 poise) at operating temperatures, and the chemically adjusted feed solutions are easier to handle than those of other flowsheets and generally produce homogenous melts. The primary disadvantage of phosphate melts is that of higher corrosion rates than with other melts such as silicates, borates, etc. Although glassy products can be made in the spray solidifier, compositions that make true glasses tend to volatilize enough of the anion fluxing agent to sometimes cause excessive condensation and pressure drop across the calciner filters. With the typical phosphate melts, microcrystalline solids are formed in spray solidification by enough phosphate addition to approach orthophosphate melts ( $\Sigma$ normality of cations: phosphorus $=2.5$ to 3.0). Sufficient alkali metals are added to reduce the melting point to 700 to $900^{\circ} \mathrm{C}$. Although the flow sheets sometimes are not compatible with the spray solidifier, glassy solids are formed by addition of more phosphate to the range of metaphosphate or hypophosphate melts ( $\Sigma$ normality of cations: phosphorus $=1.0$ to 2.0 ). 
To retain sulfate in melts, calcium is added in excess to combine chemically with the sulfate. In some cases, a small amount of aluminum is added to increase the sintering temperature for better operation in the spray calciner. Then, enough alkali metal and phosphate ions are added to reduce the melting point to about $700^{\circ} \mathrm{C}$. Some of these additions are added as solids directly to the melter to permit operation of the spray calciner with a chemical composition that has a higher melting point than that of the final melt. Sulfate volatility occurs at a slow rate at temperatures as low as $550^{\circ} \mathrm{C}$; length of time at a given temperature is important. With conditions used in the spray solidifier, $95 \%$ of the sulfate is retained in the final solid.

Up to $75 \%$ of the ruthenium can be volatilized from the spray calcination step (not during melting) with the phosphate flowsheets. This volatility can be reduced by complete elimination of melt-making flux from the feed and addition of all melt-making flux to the melter. (27) Volatility of the fission products cesium and rubidium has not occurred significantly in spray solidification flow sheets.

\section{PHOSPHATE GLASS SOLIDIFICATION}

Phosphate glass solidification is a continuous process which has been extensively developed at Brookhaven National Laboratory (BNL) and is approaching readiness for commercial use. It has been demonstrated on both a laboratory and a pilot plant scale, with no radioactivity and with full-level radioactivity. Its advantages are that it is a continuous process that produces a good quality glass product. Its disadvantages are that it is a moderately complicated system, it requires operation with slurries that are difficult to handle, it cannot retain sulfate in the final solid, and at present it requires the use of a relatively expensive platinum melter. Development requirements for specific applications are cold laboratory and modest cold pilot plant tests on actual feed compositions to determine optimum glass-making conditions and to confirm design concepts for evaporation, handling, and controlling the concentrated slurry from the evaporator. 
In phosphate glass solidification, liquid waste is continuously concentrated to a thick slurry in an evaporator from which the slurry is drawn off for conversion to a glass in a continucus melter. ${ }^{(29)}$ Liquid waste which contains all of the melt-making additives is first fed to the evaporator where it is concentrated and denitrated by factors of 3 to 10 to a thick, syrupy, aqueous phosphate slurry. The slurry is fed to the continuous melter where final volatilization of the water, nitrates, and other volatile constituents is a.ccomplished, and the material is heated to 1000 to $1200^{\circ} \mathrm{C}$ to form a molten giass. The molten glass flows through an overflow weir or a freeze valve into the receiver-storage pot below. After the pot is filled, it is cocied in the furnace, sealed, and taken to storage.

The product from the phosphate glass process is a monolithic, moderately brittle glass formed after cooling the melt. The glass has a fairly good thermal conductivity and a low solubility in aqueous solutions. See Table IV for some of the common characteristics of phosphate glass and other solidified wastes.

The basic elements of equipment required for phosphate glass solidification are (a) a continuous evaporator to concentrate the feed to syrupy consistency, (b) a means for controlled feeding of the syrupy concentrate to the melter, (c) a continuous melter for final evaporation and melting of the waste, (d) a furnace for heating the melter, (e) a pot for receiving the molten waste, and ( $f$ ) a muitipie-zoned furnace for heating and cooling the receiver pot. The last four needs are essentially identical to those in the spray solidifier.

The evaporator must have the capability to handle corrosive liquids with viscosities up to about 10 poise and boiling points up to about $150{ }^{\circ} \mathrm{C}$, with a net heat transfer capability of about $0.8 \mathrm{~kW} /$ liter $/ \mathrm{hr}$ of feed rate. Designs which provide low hold-up volume, maximize control of foaming, and maximize suspension of solids are desirable. Titanium is an acceptable construction material. 
The method of feeding the melter must have the capability of reliably pumping and metering small flow rates (about 3 liters/hr in a plant that processes wastes from 1 tonne of fuel/day) of the thick slurry from the evaporator. The feeding system must keep the slurry near its boiling point to maintain a free flow and to prevent excessive precipitation in the feedline, and must keep the temperature below calcination temperature (about $160^{\circ} \mathrm{C}$ ) as the material enters the melter. Special designs using recirculation of large flow rates have been developed for this purpose.

The continuous melter requirements are essentially the same as those discussed previously for the spray solidifier. Exceptions are that in the phosphate glass melter the net heat transfer requirements are 50 to $100 \%$ higher, primarily because of the added evaporation load, and the desired freeboard requirements above the melt level are somewhat higher because of the foaming tendency in the melter. (31) The capacity of a platinum melter that is 10 inches in diameter and has a 14 inch-high heated section is 1.2 liters/hr of glass, or about 3 liters/hr of slurry feed. $(24,32)$ The vapor stream from the melter is hot $\left(400\right.$ to $\left.600^{\circ} \mathrm{C}\right)$ and corrosive ${ }^{(33)}$ and must be routed through platinum piping until the temperature is reduced to about $120^{\circ} \mathrm{C}$.

The furnace for heating the melter is similar to that for the spray solidifier, except that the net heat load requirement is about 7 kilowatts for each liter/hr of melt formed at temperatures up to $1300^{\circ} \mathrm{C}$.

The pot for receiving the molten glass is similar to that for the spray solidification process, except that mild steel pots are satisfactory for all flowsheets. This added degree of freedom is because the lower slump point $\left(600\right.$ to $700^{\circ} \mathrm{C}$ ) and the continuous viscosity-temperature relationship for glasses, as opposed to microcrystalline solids, permits filling of pots by slow continuous dripping of melt while the pot is heated only to 400 to $600^{\circ} \mathrm{C}$. (33) Mild steel can tolerate these conditions during the filling of one pot.

The receiver furnace requirements are the same as those in spray solidification, except that the temperature requirement is reduced to about $700{ }^{\circ} \mathrm{C}$ for phosphate glass solidification. 
The phosphate glass process can readily solidify high level waste solutions which contain sulfate, but the sulfate is completely volatilized from the melter. In this case, a separate condenser is required for the vapor stream from the melter, and a separate stream of intermediate level waste is formed. This stream contains all the sulfate and normally about $30 \%$ of the nitrate, 5 to $10 \%$ of the radioruthenium, and less than $0.5 \%$ of all other radioactivity that was original in the liquid waste stream. (32) Because the sulfate cannot be reused, it requires special treatment for final disposal. When sulfate is not present, the condensate from the melter contains only nitrates and can be combined with the condensate from the denitrator-evaporator, or condensed separately and recycled to the denitrator-evaporator to reduce the overall off-gas activity from the solidifier to less than $1 \%$ for radioruthenium and $0.5 \%$ or less for all other activity.

The chemical adjustments required for the phosphate glass process consist mainly of adding phosphoric acid to the feed to obtain a metaphosphate melt ( $\Sigma$ normality of metal ions: phosphorus $=1$ ). When the mole $\%$ of the oxides of the alkali metals is less than about half of that of the total metal oxides in the melt, additional alkali metals are added to the feed (usually as sodium nitrate) to obtain a glass that forms at a reasonable temperature $\left(850\right.$ to $\left.1000^{\circ} \mathrm{C}\right)$, melts at a low temperature $\left(650\right.$ to $700^{\circ} \mathrm{C}$ ), and has good handling properties. The chemically adjusted feed to the denitrator-evaporator is usually moderately friendly-the solids are gelatinous and are readily suspended. Concentration in the denitrator-evaporator sometimes progresses through stages of foaming or heavy crystalline deposits at lower and higher than normal concentration factors. These conditions must be defined for each flowsheet. Manganese is the only known chemical which forms heavy solids in the denitrator-evaporator at normal operating conditions, and its presence should be eliminated. Plugging of pipes and dip tubes with gelatinous solids during normal flow sheet conditions can also be troublesome and must be accounted for in design of the denitrator-evaporator. 


\section{FLUIDIZED BED SOLIDIFICATION}

The fluidized bed solidification process is a continuous process that has been extensively developed for use with aluminum nitrate and zirconium fluoride-aluminum nitrate wastes. Development of fluidized bed solidification was initiated at ANL and has been extensively demonstrated by Idaho Nuclear Corporation. The process has been fully demonstrated with moderate radioactivity levels in production scale equipment since 1963 and is ready for commercial application for these wastes. Development with the more unfriendly Purex wastes has been limited. The advantages of the fluidized bed process are that it is a continuous process with a relatively high capacity for a given equipment size, and the solidified waste product is readily transportable by pneumatic means and is conducive to storage in large containers. Its disadvantages are that it is a moderately complicated system which requires a complex heating scheme for larger calciners and large hold-up of solidified waste. Development requirements for specific applications with aluminum wastes are essentially none, while cold laboratory and pilot plant tests are required for future processing of Purex wastes.

In fluidized bed solidification, liquid waste is continuously converted to granular solids by being heated in a fluidized bed of the solids, and the solids are continuously withdrawn from the calciner to storage bins (or the solids may be further converted to monolithic forms). The liquid waste is injected through pneumatic atomizing nozzles into the side of a heated ( 400 to $600{ }^{\circ} \mathrm{C}$ ) bed of granular solids which is continuously agitated (fluidized) by gas sparging upward through the fluidized bed reactor. Contact of the waste with the hot, granular bed results in evaporation and calcination of the feed as coatings of the bed particles. The calcine that is entrained with the process gases from the calciner is removed from the gas stream by cyclone separators or filters, then returned to the main stream of particles. The mainstream of particles is continuously removed from the reactor and transported to storage bins. 
The product from fluidized bed solidification is granular with a mean particle diameter of about $500 \mathrm{um}$. The granules may be composed of crystals or amorphous solids. The granules are generally spherically-shaped and are moderately soft and friable. The thermal conductivity of the bulk calcine is relatively low. (See Table IV for some characteristics of fluidized bed and other solidified products.)

The basic elements of equipment required for fluidized bed calcination are (a) an atomizing nozzle and a reactor for atomizing and calcining the feed, (b) a means for heating the bed of calcine in the reactor, (c) an off-gas cleaning system immediately downstream of the fluidized bed reactor to remove the bulk of the entrained calcine dust from the off-gases, and (d) a storage container for the calcined solids.

The atomizing nozzle must break up the feed into small droplets to be distributed over the bed of fluidized granules in the reactor to permit sufficiently rapid drying to eliminate caking. The atomized particle size requirements are not known, but commercial external-mixing pneumatic atomizing nozzles with slight modifications perform satisfactorily. $(34,35,36)$ The volume of gas generally required for adequate atomization and control of bed particle size is 400 to 600 times the volume of liquid fed. Atomization with air or superheated steam has been satisfactorily demonstrated. The stainless steel fluidized bed reactor must provide enough volume hold-up to permit adequate drying and calcining capacity without caking. This bed volume is generally in the range of 3 to 6 times the hourly volume of liquid fed to the calciner. $(34,36,37,38)$ The reactor bed usually has a length:diameter ratio in the range of $11 / 2: 1$ to $4: 1$. Higher ratios generally result in poor fluidization (spouting and slugging), while lower ratios result in poor efficiency in the use of fluidizing air. The bedcontaining portion of the reactor is usually surmounted by another section of about equal height and equal-or-larger diameter to provide for disengagement of the fluidized particles. Sufficient gas must be injected upward into the bed through an adequate distributor to fluidize the bed of granules for good heat transfer between the heating surface and the bed and between the bed and the atomized liquid. The fluidizing gas requirements vary with the size and shape of the bed particles, but are generally in the range of 0.5 to $1.5 \mathrm{ft} / \mathrm{sec}$, superficial bed velocity. $(34,35,36,37)$ 
Smaller particles provide for better heat transfer, but larger particles result in less attrition and fine dust generation. The size of particles in any bed varies from less than 1 to greater than $1000 \mathrm{wm}$ but optimum average size of particles is in the range of 400 to $600 \mu \mathrm{m} .(34,35,36,37,39)$

The amount of heat required for calcination is about 1 kilowatt for each liter per hour of liquid fed to the calciner. This heat must be provided in such a manner that the maximum temperature of the heat transfer surface is less than the sintering point of the calcine, and the heat must be distributed so that it can be absorbed by the needs of the reactor. Overall heat transfer coefficients are 25 to $50 \mathrm{Btu} / \mathrm{hr}\left(\mathrm{ft}^{2}\right)\left({ }^{\circ} \mathrm{F} / \mathrm{ft}\right)$. For small reactors (less than about 12 inches in diameter) the heat has been provided solely through the walls of the reactor, using conventional electric heating systems. $(34,35)$ For larger reactors (and for some smaller reactors), additional heat has been added through heat transfer surfaces inside the reactor bed to provide better heat distribution. Internal heat must be provided with controlled maximum temperatures to prevent localized formation of hot spots and caking. $(34,36)$ Liquid NaK has been satisfactorily demonstrated as a heat transfer fluid at the Waste Calcination Facility (WCF) at National Reactor Testing Station (NRTS), and combustion of gases is being investigated as an alternate heating method. (40) For high level wastes with high rates of self-heat generation, the fluidized bed system requires a means for cooling the contents of the bed or for dumping the bed during shutdown periods. Such provisions will eliminate the potential for self-overheating of the bed when flow of feed to the bed has stopped.

The process gases from the calciner generally entrain up to half the calcine. Consequently, a particulate removal system is required which routes most of these particulates back to the calciner or to the storage container with the rest of the calcine. Particulate removal has been satisfactorily demonstrated by the use of cyclones $(34,36,37)$ and by the use of porous stainless steel filters with periodic pulse blowback for on-line cleaning ${ }^{(35)}$ (similar to the previously discussed system for the 
spray calciner). Cyclones have the advantage of being simpler, while the filter blowback system is more efficient (about $99.5 \%$ versus about $75 \%)^{(16,41)}$ and does not require a system to motivate the removed particulates to the calciner or to the storage container. The cyclone system results in 10 to $15 \%$ of the total calcine being recycled to the calciner from downstream effluent cleanup systems.

Because of the ease of pneumatic transport of fluidized bed calcine, pneumatic transfer to the storage containers is possible once the waste is at the storage site. The pneumatic transportability of fluidized bed calcine also provides for the optional use of relatively large storage containers. Containers may be the individual pots as discussed previously, or they may be the large slab or annular containers demonstrated at the Waste Calcining Facility at Idaho Falls, Idaho. ${ }^{(42)}$ The latter geometry provides for heat removal by air or water circulating around the outsides of the concentric annuli between the concentric storage bins. Storage containers for fluidized bed calcine have been stainless steel, although the use of mild steel may be possible for use with air cooling.

The fluidized bed process has been amply demonstrated in the WCF on moderately radioactive waste with aluminum nitrate and aluminum nitrate-zirconium fluoride wastes. $(38,40,43)$ The relatively limited development that has been undertaken on Purex wastes indicates that successful calcination of the Purex wastes by fluidized bed calcination is most likely. $(35,36)$ Purex wastes are less friendly than aluminum wastes because of their greater solubility in the feed solution and their increased tendency for sticking and sintering. Although these characteristics cause increased agglomeration of particles and increased formation of lumps around the nozzle, control of agglomerate formation by impingement air jet grinding and variations in fluidizing gas rates and by simple modifications to commercial atomizing nozzles appear to solve these problems. $(35,36)$

Ruthenium volatility from aluminum nitrate wastes varies from less than $1 \%$ at $550{ }^{\circ} \mathrm{C}$ to greater than $90 \%$ at $350^{\circ} \mathrm{C}$, ${ }^{(35)}$ with an average volatility of $40 \%$ in the WCF operating at $400^{\circ} \mathrm{C} .{ }^{(43)}$ Addition of chemical reductants greatly reduces volatility of ruthenium. Volatility from Purex wastes at $500{ }^{\circ} \mathrm{C}$ was about $70 \%$, and was reduced to about $1 \%$ when sugar (a chemical reductant) was added to the feed. (35) 
Sulfate is retained with the calcine (greater than 99\%) in fluidized bed calcination of Purex waste. (35) At $400^{\circ} \mathrm{C}$ operating temperature, the calcine contains about $5 \%$ of the original nitrate, while at $500{ }^{\circ} \mathrm{C}$, the calcine contains about $0.1 \%$ of the nitrate.

Fluoride is retained with the calcine (99\%) and corrosion is controlled in fluidized bed calcination of zirconium fluoride-aluminum nitrate wastes by the chemical addition of calcium in stoichiometric equivalence to the amount of fluoride present. (18) 


\section{CHAR ACTER ISTICS OF SOLIDIFIED WASTE}

The three conditions that will determine the desirable characteristics of solidified waste are:

(1) Interim storage,

(2) Transportation to long-term storage,

(3) Long-term storage.

In any specific application, items 1 and 3 may be identical, and item 2 may effectively disappear if long-term storage is at the site where solidification is done. The basic criterion is that radioactivity beyond safe limits is not permitted to enter the human environment. The desired characteristics of solidified waste with primary importance are:

- Good thermal conductivity

- Low leachability by water (or possibly air)

- Good chemical stability and radiation resistance

- Mechanical ruggedness

- Noncorrosiveness to container

- Minimum volume

- Minimum cost

- Retrievability

Quantitative discussion of each of these characteristics is not possible without a detailed analysis of a specific case. However, a brief qualitative discussion is presented.

Good thermal conductivity is obviously desired to remove the heat of radioactive decay from the outer wall of the solidified waste with a minimum temperature rise to the center of the waste. The temperature difference from the center to the wall of a solid cylinder of self-generating heat varies as:

$$
\begin{aligned}
\Delta \mathrm{T} \propto \frac{1}{\mathrm{k}} \cdot \mathrm{Q} \cdot \mathrm{r}^{2} \text { where } \Delta \mathrm{T} & =\text { temperature difference } \\
\mathrm{k} & =\text { thermal conductivity } \\
\mathrm{Q} & =\text { specific heat/unit volume } \\
\mathrm{r} & =\text { radius of cylinder }
\end{aligned}
$$


A lower thermal conductivity will linearly increase the temperature at the center of a given pot, or will reduce the amount of self-generating heat that can be included in a pot, or will reduce the allowable size of a pot. The net effect of lower thermal conductivity is to reduce the amount of allowable heat stored in a pot. In addition, this limitation results in undesirable increases in the amount of time that liquid waste must be stored before solidification, or it increases the minimum volumes for solidified wastes. These effects are summarized in Figure 2 for values that are typical for wastes from thermal reactors. The heat content of wastes from future fast reactors can be 5 times those in Figure 2 for the first few years.

Low leachability of the solidified products is desired to minimize the amount of activity in water that would reach animal life, in the event that such water enters the storage cavern and contacts a breached container. If true ultimate disposal is accomplished where waste is definitely and permanently out of man's environment, leachability is only of importance during the interim storage period and during the transportation to the ultimate disposal site. The leachability and other characteristics of solidified wastes made by the processes developed in the USA are shown in Table IV. (The leachability of processes developed elsewhere is also covered by the range in Table IV.) The following example provides an indication of perspective for ideal leachability: if one square centimeter of solidified waste were to be safely contacted by one liter of potable water for one minute, the leach rate must not exceed $1 \times 10^{-10} \mathrm{~g} / \mathrm{cm}^{2} \mathrm{x}$ day, or a leach rate about ten thousand times lower than the best shown in Table IV. * Because actual leach rates are many times greater than ideal, when such

Using $100,000 \mathrm{C}_{1}$ of ${ }^{90} \mathrm{Sr}$ per cubic foot of solidified waste for 45,000 MWd/tonne exposure), and the 168 hour MPC value of $1 \times 10^{-10} \mathrm{iCi} / \mathrm{m}^{3}$ for ${ }^{90} \mathrm{Sr}$. (1) 


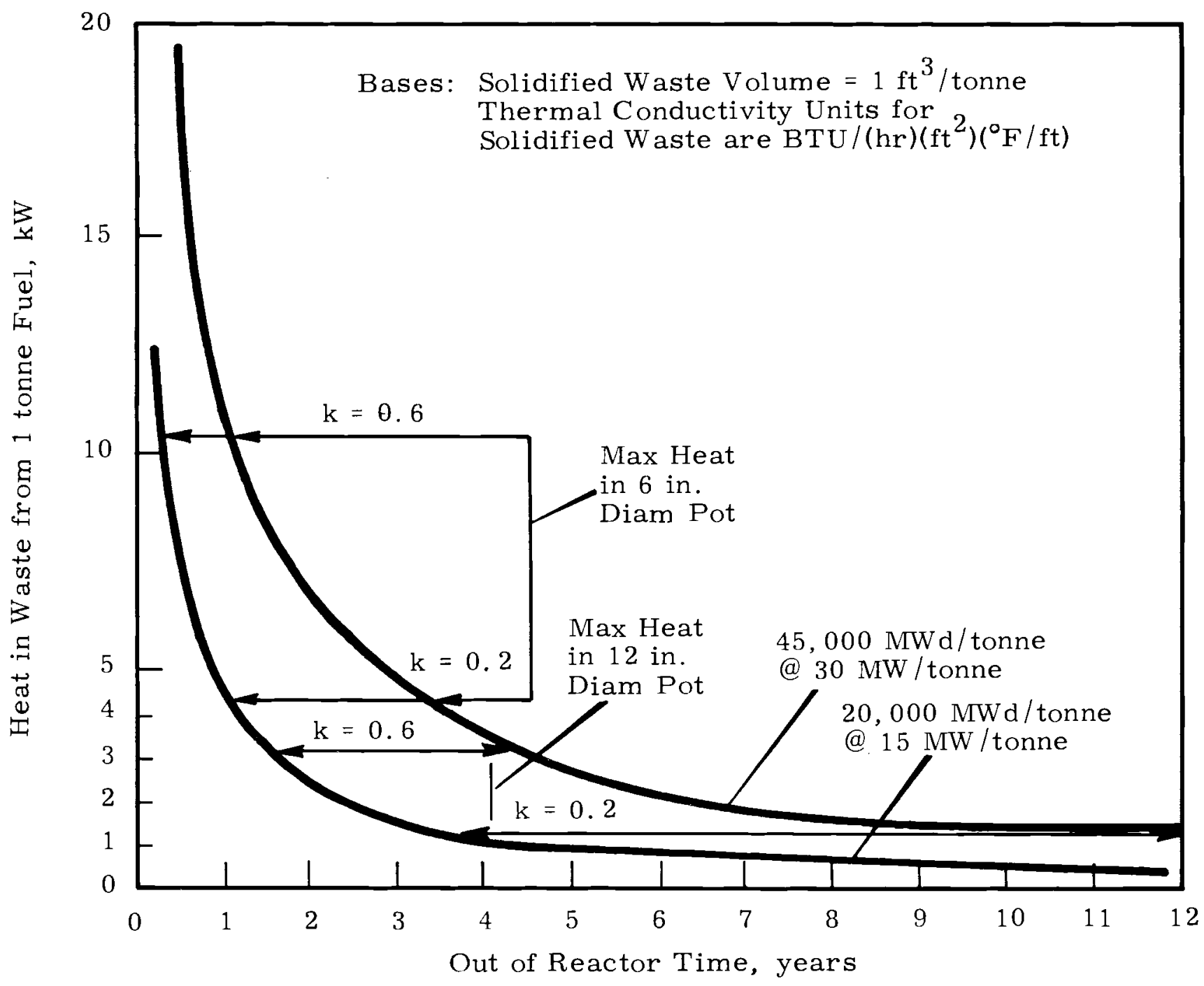


TABLE IV. Characteristics of Solidified High-Level Waste

\begin{tabular}{|c|c|c|c|c|}
\hline & $\begin{array}{c}\text { Pot } \\
\text { Calcine } \\
\end{array}$ & $\begin{array}{l}\text { Spray } \\
\text { Melt }\end{array}$ & $\begin{array}{c}\text { Phosphate } \\
\text { Glass } \\
\end{array}$ & $\begin{array}{c}\text { Fluid } \\
\text { Bed }\end{array}$ \\
\hline Form & Monolithic & Monolithic & Monolithic & Granular \\
\hline Description & Scale & Microcrystalline ${ }^{(a)}$ & Glass & Amorphous ${ }^{(b)}$ \\
\hline \multicolumn{5}{|l|}{$\begin{array}{l}\text { Chemical Composition, } \\
\text { mole \% }\end{array}$} \\
\hline Fission product oxides & 15 to $\sim 80$ & 5 to 30 & 5 to 25 & 5 to $50^{(\mathrm{c})}$ \\
\hline Inert metal oxides & 10 to 50 & 40 to 50 & 10 to 30 & 10 to $>90$ \\
\hline Sulfur oxides (if in waste) & 0 to 40 & 0 to 40 & & 0 to 40 \\
\hline Phosphor ous oxides & $\sim 0$ & 25 to 40 & $\sim 60$ & $\sim 0$ \\
\hline Bulk Density, $\mathrm{g} / \mathrm{ml}$ & 1.1 to 1.5 & 2.7 to 3.2 & 2.7 to 3.0 & 1.0 to 1.7 \\
\hline $\begin{array}{l}\text { Thermal Conductivity, } \\
\text { Btu/hr } \mathrm{x} \text { ft } \mathrm{x}{ }^{\circ} \mathrm{F}\end{array}$ & 0.15 to 0.25 & 0.4 to 0.8 & 0.4 to 1.0 & 0.10 to 0.25 \\
\hline$\underset{\text { solid }}{\operatorname{Maxim}(d)}$ Heat, W/ liter & 85 & 210 & 210 & 70 \\
\hline $\begin{array}{l}\text { Leachability in Cold Water } \\
\qquad \mathrm{g} / \mathrm{cm}^{2} \text {-day }\end{array}$ & 1.0 to $10^{-1}$ & $10^{-3}$ to $-10^{-6}$ & $10^{-4}$ to $10^{-7}$ & 1.0 to $10^{-1}$ \\
\hline Hardness & Soft & Hard & Very Hard & Moderate \\
\hline Friability & Crumbly & Tough & Brittle & Moderate \\
\hline Residual Nitrate, wt $\%$ & $\leq 0.05$ & $\leq 0.005$ & $\leq 0.005$ & $\leq 4.0$ \\
\hline
\end{tabular}

(a) Glassy products can also be made with some difficulty.

(b) Microcrystalline products can also be made.

(c) Composition ranges for fluid bed are also for Purex waste and are estimated.

(d) Approximate values for storage in air in 8 inch diameter cylindrical pots to maintain pot centerline temperatures less than $900^{\circ} \mathrm{C}$ and pot wall temperatures less than $425^{\circ} \mathrm{C}$. Average $\mathrm{k}$ values were used. 
water contacts the solidified waste, the waste must be in a sealed container or the water must be treated before use by animal life. The useful life of the containers is not known at this time but is expected to be much longer than the 15 to 40 years for containers for liquid wastes. $(44,45)$ Another means for comparison between storage of liquid versus solid wastes is that the solidified wastes with the lowest known leachability offer improved protection from contamination of water by a factor of about one million compared to liquid wastes.

Generally, leach rate of a melt-solidified waste decreases as the solidification temperature is increased, and decreases with increased glassiness of the material. $(9,10)$ Devitrification of many glasses into microcrystalline materials can and does occur with extended periods at high temperatures and with slow cooling. $(10,46,47,48,49,50)$ (It is therefore possible that glasses will devitrify under "normal" processing and storage conditions.) When devitrification occurs, leachability is increased by about an order of magnitude. (49) On first contact with water, leachability of melt-solidified waste is relatively high; then over a period of 10 to 50 days decreases by about a factor of 10 to a relatively steady rate. $(48,50,51)$

Chemical stability and resistance to radiation of solidified waste are important primarily to assure that gases which may significantly affect the integrity of the product (or container, if present), are not generated during storage and secondarily, to assure that the basic structure and properties of the solidified waste are known. The generation of gases would only be caused by the presence of potentially volatile constituents (i.e., nitrates, water, or sulfates) in combination with high temperatures. Experience to date indicates that gas formation from solidified waste in enclosed containers is generally not significant if storage temperature does not approach processing temperature. $(42,47,48,52,53)$ A few exceptions have been indicated, however, for calcine from feeds with high sodium nitrate content (nitrogen oxide volatility) $^{(52)}$ and for some phosphate-sulfate melts (sulfur oxide volatility). (54) Consequently, measurements on nonradioactive 
solidified wastes of specific chemical compositions should be made before predictions of gas formation at near-processing temperatures can be done. At temperatures above processing temperatures, volatilization of some "nonvolatile" constituents has been found. For example, at $800^{\circ} \mathrm{C}$, significant volatilization of cesium and ruthenium occurs from alumina solids made from the fluidized bed process; (42) at $1200{ }^{\circ} \mathrm{C}$ or higher, boron is volatilized from borosilicate glasses and some phosphate is volatilized from phosphate melts. (48)

The basic structure and chemical properties of solidified waste definitely change with time because about $30 \%$ of the fission products present after 6 months out of the reactor will eventually decay to other chemical elements. For calcines, this $30 \%$ represents up to $25 \%$ of the oxides present in the total waste, and for melts it represents up to $10 \%$ of the oxides present. Definition of these changes in properties and their effects is not well known. Some glasses will devitrify to microcrystalline structures if held at 400 to $800{ }^{\circ} \mathrm{C}$ for days or weeks. $(10,46,47,48,49,50)$ calcined alumina granules change from amorphous to crystalline form, ${ }^{(42)}$ some volatile constituents migrate from thermally hot locations and condense at cooler locations, ${ }^{2}$ and phosphates and other glasses sometimes exude liquids. $(46,47)$

Mechanical ruggedness of the solidified waste package is desirable primarily during transportation. The properties of the solidified waste contents may enhance the ruggedness of the container. In the event the container is breached, the ruggedness of the solidified waste is important in terms of its tendency to be dispersed. A waste that has low leachability but is very britle or easily scattered may contaminate the environs to the same degree that a physically rugged waste with righer leachability would. in other cases, a waste that generates gases during storage may require a more rugged container.

Corrosiveness of the solidified waste to the container determines, in part, the life of the container. Corrosion of containers by solidified wastes has indicated no problem areas in limited measurements to 
date, $(25,26,27)$ but very long-term effects have not been evaluated. Volatility of some constituents from the solid waste, such as sulfur oxide, may cause significant corrosion.

Minimum volume is important primarily for economic reasons. In general, reducing the volumes will reduce the size and cost of containers, of container storage areas, of shipping equipment, and land for storage areas. Minimizing cost, without affecting quality, is an obvious merit.

One unresolved concern in the ultimate disposal of radioactive wastes is that of desired waste characteristics and storage system versus retrievability of the waste. Since wastes must truly be kept under control "forever" when stored on earth, allowance should be made for the uncertainty of nature over the very long time period of concern. Therefore, provisions for retrieving the waste are most desirable for potential reprocessing for various reasons, or because the storage vault is "worn out." Where ready retrievability is provided, the solidified waste package may be permitted to have somewhat less desirable characteristics compared to those of a solidified waste package with better integrity in a poorly retrievable storage system. Comparable safety may be provided in either case. Similarly, the more easily retrievable storage systems will generally provide greater safety for the very long term by keeping the waste under control during unforeseen occurrences. 


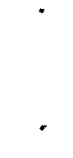


NEAR - FUTURE TECHNOLOGY

The technology of solidification has progressed to the point that three of the major processes in the USA are being demonstrated with full-activity-level wastes in engineering-scale equipment, and the fourth major process has been demonstrated with intermediateactivity-level wastes in large-scale equipment for five years. Most of the basic technology has been obtained, nonradioactive development work is nearly completed, and fully radioactive tests are in progress. No other more promising processes are known at this time.

The modest amount of nonradioactive development work on solidification processes now in progress in the USA is expected to be completed within the next two years, unless new applications arise. A small amount of laboratory-scale flowsheet work may continue beyond that time for special problems. Current work includes that on fluid bed calcination at ICPP, phosphate glass solidification at BNL, and spray solidification at BNW. At the completion of these studies, basic process and equipment technology will have been developed for general use.

Also during the next two years, demonstration of the three processes in the Waste Solidification Engineering Prototypes (pot, spray, and phosphate glass solidification) on Purex wastes will have been completed. The processes will have been demonstrated using fully radioactive wastes with maximum heat (perhaps as high as $400 \mathrm{~W} /$ liter of solid) and high fission product content (from 45, $000 \mathrm{MWd} /$ tonne thermal reactors operating at $30 \mathrm{MW} /$ tonne.) The operation of the fluid bed calcination facility at ICPP will continue to convert aluminum nitrate and zirconium fluoride wastes to granular calcine having a heat content of about $1 \mathrm{~W} /$ liter.

In about three years, the fluid bed solidification system at the Midwest Fuel Recovery Plant (Generai Electric Company) will be converting Purex wastes, diluted with aluminum nitrate, to solidified granular calcine having a heat content of about $200 \mathrm{~W} /$ liter of solid. 
Within three to five years, the characteristics of the solids generated in the WSEP program will have been measured and evaluated for the first few years following solidification. ${ }^{(55)}$ This time period is when the solid is at its highest temperature and when about half the total radiation dose is obtained. Measurements will be taken on core-drilled specimens from actual solidified wastes. Also during this time period, characteristics of solids generated in the ICPP and stored at higher temperatures (about $700{ }^{\circ} \mathrm{C}$ ) will have been investigated. (41)

Also during the next three to five years, current data $(45,56,57)$ on economics of waste solidification and its management will be updated and well defined. $(55)$

Within the next few years, the AEC's waste solidification development program of currently-known concepts will be completed. The general cold development work for solidification will have been completed, based on the use of the Purex separations process; the solidification processes will have been tested with full levels of radioactivity; the processes will have been demonstrated using wastes from advanced high-exposure thermal reactors which contain large quantities of fission products; and effects of severe temperature and radiation on the properties of the solidified waste products will have been measured and evaluated. The technology obtained from the program will be as complete as reasonably possible. It will provide reliable bases from which to make proper decisions on management of high-level wastes, and it will provide realistic bases for design, operation, and safety of waste solidification plants.

At least a small amount of developmental effort on any process in the nuclear fuel reprocessing industry, including waste solidification, will be required for any specific application which has not been previously demonstrated. The development requirements may be limited to laboratory tests, but because of the high degree of reliability needed in the nuclear fuel reprocessing industry, a short demonstration program in pilot plants is frequently warranted. 


\section{REFERENCES}

1. U. S. Department of Commerce, National Bureau of Standards Handbook 69, Maximum Permissible Body Burdens and Maximum Permissible Concentrations of Radionuclides in Air and in Water for Occupational Exposure, USA Standards Institute. August, 1963.

2. "Proposed Definition of Radioactive Waste Categories, " A. I. Ch. E., USA Standards Institute. 1967.

3. D. W. Clelland. "Concentration and Storage of Highly-Active Waste from the First Stages of the United Kingdom Civil Nuclear Power Programme," SM 31/2, (Vienna Paper). October, 1962.

4. M. Chambon and J. Rodier. Concentration and Storage of Fission Products at Marcoule Plutonium Extractor Plant, AERE-Trans-938: Atomic Energy Research Establishment, Harwell, Berks, England, December, 1962.

5. P. Gaugeras. Problem of Storing the Fission Products Resulting from the Processing of Irradiated U-Mo Alloys, AERE-Trans-939. Atomic Energy Research Establishment, Harwell, Berks, England, December, 1962.

6. J.M. Holmes. Survey of Nuclear Fuel Services, Inc, Waste Compositions, ORNL-TM-1013. Oak Ridge National Laboratory, Oak Ridge, Tennessee, December 7, 1964.

7. Design and Analysis, Midwest Fuel Recovery Plant, General Electric Company, Docket 50-268-1, November, 1966.

8. J.E. Mendel, G. Rey, and J.L. McElroy. "Design Verification Testing of Waste Solidification Processes, " CONF-660208. Richland Symposium, February, 1966.

9. G. B. Barton. Solidification of High Level Wastes, Part IV, Phosphate Melts for Fixation of Radioactive Residues from Purex Type Wastes, Three to Fifty Percent Fission Product Oxides, BNWL-80. Pacific Northwest Laboratory, Richland, Washington. July, 1965 .

10. G. B. Barton. Solidification of High Level Wastes, Part V, a Factorial Study of the Effect of Varying the Concentration of the Components of Purex Type Waste on the Properties of Phosphate Solids, BNWL-544. Pacific Northwest Laboratory, Richland, Washington. January, 1968. 
11. G. B. Barton. Solidification of High Level Wastes, Part VI, Mixed Phosphate, Borate, Silicate Melts for Fixation of Purex Type Wastes, BNWL-373. Pacific Northwest Laboratory, Richland, Washington. January, 1967.

12. J. E. Mendel. "Preparation of Melts from Solidified Waste," Quarterly Progress Report, Research and Development Activities, Fixation of Radioactive Residues, A. M. Platt, Editor, BNWL-76。 Pacific Northwest Laboratory, Richland, Washington, January-March, 1965.

13. W. E。 Clark and H. W. Godbee. "Fixation of Simulated Highly Radioactive Wastes in Glassy Solids, "Vienna Symposium, October, 1962 .

14. K. D. B. Johnson, J。 R. Grover, and W. H. Hardwick. "Work in the United Kingdom on Fixation of Highly Radioactive Wastes in Glass." A/CONF. 28/p. 188, Geneva Symposium, 1964.

15. R. Bonniaul. "Survey of the Studies Conducted in France on the Solidification of Concentrated Fission Product Solutions, " CONF。-660208. Richland Symposium, February, 1966.

16. J。D. Kaser and J。D. Moore. "The Development of a Spray Calciner-Melter," CONF。-660208. Richland Symposium, February, 1966.

17. J.E. Mendel. "Pot Solidification Process Technology," Quarterly Progress Report, Research and Development Activities, Fixation of Radioactive Residues, A. M. Platt, Editor, BNWL-434. Pacific Northwest Laboratory, Richland, Washington, January-March, 1967.

18. J.C. Petrie, E.J. Bailey, D.W. Rhodes, and B. M. Legler。 Fluidized Bed Calcination of Simulated Zirconium Fluoride Wastes in Exploratory Pilot Plant Tests, IDO-14653. Philips Petroleum Company, Idaho Falls, Idaho. July, 1965.

19. R. F. Maness. Unpublished Data. Pacific Northwest Laboratory, Richland, Washington, April, 1968. (Undocumented Laboratory Tests)

20. W. E. Clark and C. L, Fitzgerald. Proposed Means for the Removal of Mercury from Radioactive Waste Solutions, ORNL-TM-827. Oak Ridge National Laboratory, Oak Ridge, Tennessee, March, 1964. 
21. J. L. McElroy, C. R. Cooley, W. V. DeMeir, J. E. Mendel, J. O. Blomeke, and J. C. Suddath. Pot Calcination Performance During First Radioactive Tests in Waste Solidification Engineering Prototypes: Waste Solidification Program, vol. 4, BNWL-814. Pacific Northwest Laboratory, Richland, Washington. (In Progress)

22. M. R. Schwab. Unpublished Data. Pacific Northwest Laboratory, Richland, Washington. June, 1966. (Data from WSEP Demonstrations)

23. H. W. Godbee and J. T. Roberts. Laboratory Development of a Pot Calcination Process for Converting Liquid Wastes to Solids, ORNL-2986. Oak Ridge National Laboratory, Oak Ridge, Tennessee, August 30, 1961.

24. K. J. Schneider and V. P. Kelly. "Design Features of the Waste Solidification Engineering Prototypes, "CONF. -660208. Richland Symposium, February, 1966.

25. R. F. Maness. Unpublished Data. Pacific Northwest Laboratory, Richland, Washington. 1965. (Laboratory Data)

26. G. Rey, Editor, Unpublished Data. Pacific Northwest Laboratory, Richland, Washington. April, 1966. (Waste Solidification Engineering Prototypes Technical Manual, Chapter 6).

27. W. R. Bond. "Developmental Spray Calciner Runs," Quarterly Progress Report, Research and Development Activities, Fixation of Radioactive Residues, A. M. Platt, Editor, BNWL-677. Pacific Northwest Laboratory, Richland, Washington. July-October, 1967.

28. J. D. Moore and K. J. Schneider. "Radioactive Demonstration of Spray Solidification, "Quarterly Progress Report, Research and Development Activities, Fixation of Radioactive Residues, A. M. Platt, Editor, BNWL-507. Pacific Northwest Laboratory, Richland, Washington, April-June, 1967.

29. E. J. Tuthill, G. G. Weth, L. C. Emma, G. Strickland, and L. P. Hatch. "Phosphate Glass Process for Disposal of High Level Radioactive Wastes, "I \& EC Process Design and Development, vol. 6. July, 1967.

30. G. Strickland, E. J. Tuthill, and R. F. Drager. "Phosphate Glass Process: Evaporator Studies with Simulated Purex Wastes, " CONF. -660208. Richland Symposium, February 1966.

31. G. G. Weth, G. Strickland, and E. J. Tuthill. "Platinum for High Temperature Crucible Used in Processing Radioactive Waste, "CONF. -660208. Richland Symposium, February, 1966. 
32. J。 L。 McElroy and Ko J. Schneider. Unpublished Data. Pacific Northwest Laboratory, Richland, Washington. April, 1968. (Data from WSEP Demonstrations).

33. M. E. Spaeth and M. R. Schwab. Unpublished Data. Pacific Northwest Laboratory, Richland, Washington. April, 1968. (Data from WSEP Design Verification Testing).

34. L. T. Lakey, G. E. Lohse, and W. P. Palica. Development of Fluidized Bed Calcination of Aluminum Nitrate Wastes in the Waste Calcining Facility, IDO-14608. Phillips Petroleum Company, Idaho Falls, Idaho, May, 1965.

35. J.W. Loeding, E. L。Carls, L。J.Anastasia, and A. A. Jonke. The Fluid Bed Calcination of Radioactive Waste, ANL-6322. Argonne National Laboratory, Lemont, Illinois, May, 1961.

36. M. D. Alford. Fluidized Bed Calcination of Simulated Purex HighActivity Level Wastes, HW-66384-RD. Available from Clearinghouse for Federal Scientific and Technical Information, Springfield, Virginia, September 1, 1960 .

37. K. J. Schneider. Fluidized Bed Calcination Studies With Simulated ICPP Waste Solution, HW-65838-RD. Available from AEC Division of Technical Information Extension, Oak Ridge, Tennessee, June 6, 1960 。

38. G. E. Lohse. "Initial Operation of the Idaho Waste Calcining Facility with Radioactive Feed, "CONF。-660208. Richland Symposium, February, 1966.

39. E. S. Grimmett. Particle Growth and Size Distribution in Fluidized Bed Processes - $f$ Mathematical Model with Computer Solutions, IDO-14650. Phillips Petroleum Company, Idaho Falls, Idaho, April, 1966.

40. Chemical Technology Branch Progress Report, January, 1968, edited by J.A. Buckham. Idaho Nuclear Corporation, February 2, 1968 .

41. R. D. Modrow and L. T. Lakey. Removal of Particulates from Waste Calcining Facility Off-Gas, IDO-14607. Phillips

Petroleum Company, Idaho Falls, Idaho, June, 1964.

42. D. W. Rhodes. "Storage and Further Treatment of Product from Fluidized Bed Calcination of Radioactive Wastes, "CONF, -660208. Richland Symposium, February, 1966. 
43. R. E. Commander, G. E. Lohse, D. E. Black, and E. D. Cooper. Operation of the Waste Calcining Facility with Highly Radioactive Aqueous Waste, IDO-14662. Phillips Petroleum Company, Idaho Falls, Idaho, June, 1966.

44. D. W. Clelland. "Storage of Highly Active Wastes in the United Kingdom," CONF. -660208. Richland Symposium, February, 1966.

45. W. L. Lennemann. "A Look at Long Range Management Costs at U.S.AEC Sites, "CONF. -660208。 Richland Symposium, February, 1966.

46. P. B. Zimakov et al. "Treatment and Storage of High-Level Radioactive Waste, "STI/PUB/63. Vienna Symposium, October, 1962 .

47. U. L。 Upson. "Observed Properties of Some Solidified-High-Level Wastes and Their Stability Under Simulated Storage Conditions, " CONF。-660208. Richland Symposium, February, 1966.

48. J. R. Grover and M. N. Elliot. "Long-Term Examination of Glasses for the FINGAL. Process, "CONF.-660208. Richland Symposium, February, 1966.

49. G. B. Barton. "Effects of Compositional Variation on Drip Temperature and Leachability of Phosphate Solids Under Consideration for Fixation of Radioactive Residues, "CONF. -660208. Richland Symposium, February, 1966.

50. R. Bonniaud et al. "Vitrification of Concentrated Solutions of Fission Products: Study of Glasses and Their Characteristics, " Vienna Symposium, October, 1962.

51. J. E. Mendel. "Laboratory Studies on Product Characteristics and Storage from WSEP, "Quarterly Progress Report, Research and Development Activities, Fixation of Radioactive Residues, January-March, 1967, A. M. Platt, Editor, BNWL-434.

Pacific Northwest Laboratory, Richland, Washington, June, 1967.

52. R. T. Allemann, F. P. Roberts, and U. L. Upson. Solidification of High-Level Radioactive Reprocessing Wastes by Spray and Pot Calcination--Hot Cell Pilot Plant Studies, HW-83896. Available from AEC Division of Technical Information Extension, Oak Ridge, Tennessee, September, 1964.

53. W. V. DeMier. "Measurement, Techniques and Equipment for Product Characteristics and Storage from WSEP, "Vienna Symposium, October, 1962 . 
54. J. E. Mendel. Unpublished Data, Pacific Northwest Laboratory, Richland, Washington. February, 1968. (Unpublished Data).

55. C. R. Cooley and A. M. Platt. "The Waste Solidification Engineering Prototypes Technical Program, "CONF. -660208. Richland Symposium, February, 1966.

56. J. O. Blomeke et al. "Estimated Costs of High-Level Waste Management, "CONF。-660208. Richland Symposium, February, 1966.

57. J. J. Perona, R. L. Bradshaw, J. T. Roberts, and J. O. Blomeke. "Economic Evaluation of Tank Storage and Pot Calcination of Power Reactor Fuel Reprocessing Wastes, "Vienna Symposium, October, 1962 . 


\section{DISTRIBUTION}

No. of

Copies

\section{OFFSITE}

AEC Chicago Patent Group

G. H. Lee

AEC Division of Technical Information Extension

AEC Division of Naval Reactors

R. S. Brodsky

AEC Division of Production

W. L. Lennemann

AEC Division of Reactor Development and Technology

C. N. Bartlett

W. G. Belter

W. H. McVey

A. J. Pressesky

W. H. Regan

AEC Division of Space Nuclear Systems

F. C. Schwenk

2

AEC Idaho Operations Office

P. O. Box 2108

Idaho Falls, Idaho 83401

K. K. Kennedy

B. L. Schmalz

AEC Oak Ridge Operations Office

C. S. Shoup

Allied Chemical Corporation

Nuclear Fuels Department

P. O. Box 70

Morristown, N. J.

R. L. Newman 
No. of

Copies

2

Argonne National Laboratory

S. Law roski

J. Loeding

1

Argonne National Laboratory

East Area EBR-2

National Reactor Testing Station

Scoville, Idaho

P. Fineman

1

Atomic Energy Commission

Minister of Defense

Rehovoth, Israel

Yehuda Feige

4

Atomic Energy of Canada Limited

C. A. Mawson

I. L. Ophel

L. C. Watson

J. Woolston

5

Atomic Energy Research Establishment

Harwell, Didcot, Berks, England

R. H. Burns

H. J. Dunster

W. H. Hardwick

K. D. B. Johnson

W. Wild

3

Australian Atomic Energy Commission

Research Establishment

Private Mail Bag

Sutherland, New South Wales, Australia

M. G. Bailie, Chemical Engineering Section

R. C. P. Cairns

L. Keher

Brookhaven National Laboratory

R. F. Drager

L. P. Hatch

E. J. Tuthill (2) 
No. of

Copies

5

Center for Nuclear Studies

P.O.-Box 6, Fontenay-aux-Roses

(Seine), France
R. Bonniaud
F. Laude
J. Pomerola
P. J. Regnaut
$\mathrm{J}$. Sauteron

1

Center for Nuclear Studies

P.O. Box 269

Grenoble (isere), France

M. G. Wormser, Chemistry Division

Center for Nuclear Studies

P.O. Box 2, Saclay

Gif - sur-Yvette

(Seine-et-Oise), France

C. Gailledreau

A. Menoux

Andre J.Raggenbass

Center for Study of Nuclear Energy (C.E. N.)

Mol, Belgium

L. Baetsle

P. Dejonghe

1

Commissaire Boite

Postale No. 149

Paris (15 eme), France

F. Dumahel

1

Commissariat a L" Energie Atomique

Cadarache, France

P。E。Pottier

Dow Chemical Company (AEC)

D. L. Ziegler

6

du Pont Company, Aiken (AEC)

R. M. Girdler

C. H. Ice

L. H. Meyer

C. M. Patterson

E. B. Sheldon

D. S. Webster 
No, of

Copies

1

1

1

2

2

1

1

1 du Pont Company, Wilmington (AEC)

$\mathrm{J}$. R. Thayer

The E.F. MacDonaild Company

Touramerica Division

New York, New York

Fred Herber-Oettgen

EURATOM

Cassella Postale No. 1

Ispra, Italy

M. Lindner

Eurochemic Library

Mo1, Belgium

General Electric Company

Atomics Products Division

P.O. Box 450

Palo Alto, California 94306

C.R.Anderson

R. G. Barnes

General Electric Company, Pleasanton

W. H。Reas

General Dynamics Co.

San Diego, California

$\mathrm{J}$ 。 J Shefeik

George Washington University

Washington, D。C.

C.R. Naeser

Geotechnical Corporation

Box 28277, Dallas, Texas

D。W.B. Heroy

Grupo de Combustibles Irradiados

Junta de Energia Nucl.

Div。 de Mat, Civdat Univ.

Madrid 3, Spain

Federico de Lova Soria 
No. of

Copies

1

Hahn-Meitner Institut

100 Glienicker Street

1 Berlin 39, Germany

Hans W。 Levi

1

Harvard University

Cambridge, Massachusetts

H. A, Thomas, Jr.

Idaho Nuclear Corporation

J. A. Buckham

C.M. Slansky

B.R.Wheeler

1

Illinois State Geological Survey Division

Urbana, Illinois

J. C. Frye

India Atomic Energy Establishment Trombay Engineering Hall No. 5

Bombay 73, India

Keshave Chandra

Jitender D. Sehal

$\mathrm{K}$. T. Thomas

Johns Hopkins University

513 Ames Hall

Baltimore, Md. 21218

$\mathrm{J}$ 。 Geyer

W.A. Patrick

A. Wolman

1

Kansas State Health Department

Topeka, Kansas

S. J.Reno

Karlsruhe Nuclear Research Center

Decontamination Dept.

75 Karlsruhe

Siemensallee 83, West Germany

Helmut Krause 
No. of

Copies

1

1

2

1

1

1

2

1

Karlsruhe Nuclear Research Center

Waste Storage Dept.

Leopoldshafen/Bd.

Max-Plandk-Str.12,

West Germany

H. F. Ramdohr

KFA

Director of Waste Treatment Juelich, Germany

S. Rottay

Lawrence Radiation Laboratory, Berkeley (AEC)

D. B. Lombard

W. J. Kaufman

Los Alamos Scientific Laboratory (AEC)

C.W. Christenson

Mining Academy Clausthal

Petrology, Mineralogy, \&

Economic Geology Dept.

Siemensalle, West Germany

H. F. A. Borchert

Minister of Federal Property

Const. Dept.

Bad Godesberg, West Germany

G. M。K. Klinke

Mound Laboratory (AEC)

S. Freeman

J. J. Goldin

MPR Associates, Ine.

815 Connecticut Avenue, N.W.

Washington, D.C. 20006

Theodore Rockwell, III,

Chairman. AIF Safety Task Force 
No. of

Copies

N.Y. State Atomic \& Space Development Authority 230 Park Ave.

New York, N. Y.

O. Townsend, Director

1

William A. Nixon

656 South Illinois St.

Arlington, Virginia 22204

2

Nuclear Fuel Services, Inc.

P. O. Box 124

West Valley, N. Y. 14171

J. P. Duckworth

W. G. Urban

Nuclear Materials and Equipment Corporation (AEC)

Nuclear Design and Development

M. Selman, Mgr.

Nuclear Reactor Des. Sect.

Nuclear Power Plant Dept.

Hitachi, Ltd., Hitachi Works

Hitachi-Shi Ibaraki-Ken, Japan

A. Shimozato

Oak Ridge National Laboratory (AEC)

Central Research Library, Document Reference Sect.

Central Research Library, ORNL

Laboratory Records Dept., ORNL

Laboratory Records Dept., ORNL-RC

1

Office of Civil Defense

Washington, D. C.

W. J. Lacy

1

Plutonium Extraction Plant

Marcoule, France

C. J. Jouannaud 
No. of

Copies

1

Princeton University

Princeton, N.J.

$H$. H. Hess

2

Radiation Protection Dept.

Luisenstrasse 46 .

Bad Godesberg, West Germany

H。 M Holtzem

G. Straimer

1

Tokai Refinery

At. Fuel Corp.

Tokai-Mura

Ibraki-Ken, Japan

M. Ichikawa

8

Union Carbide Corporation (ORNL)

P. S. Baker

R.E.Blanco

J. O. Blomeke

W.C. Clark

F. M. Empson

$\mathrm{H}$. B. Godbee

J. C. Suddath

M. E. Whatley

1

University of Arizona

Tucson, Arizona

E. S. Simpson, Professor of Geology

1

University of Minnesota

Environmental Health Research

and Training Center

Room 1108 . Mayo Building

School of Public Health

Minneapolis, Minn. 55455

C. P. Straub

1

University of North Carolina

Chapel Hill, North Carolina

$\mathrm{H}$. C. Thomas 
No. of

Copies

1

University of Texas

Austin, Texas

E. R. Gloyna

1

University of Wisconsin

Madison, Wisconsin

H. Gladys Swope

2

U. S. Bureau of Mines

Washington, D. C.

J.E.Crawford

$\mathrm{J}$. W. Watkins

1

U. S. Geological Survey

Washington, D.C.

R. L. Nace

1

U. S. Public Health Service

Winchester, Massachusetts

D. Moeller

1

USDA National Agricultural Library

Current Serial Record (G)

Washington, D, C. 20250

1

Vanderbilt University

Nashville, Tennessee

P.A. Krenkel

\section{ONSITE-HANFORD}

AEC Chicago Patent Group

R. K. Sharp (Richland)

AEC Richland Operations Office
J. T. Christy
O. J. Elgert (2)
J. E. Goodwin
C. L. Robinson 
No. of

Copies

2

15

3

2

83
AEC RDT Site Rep., Richland

P. G. Holsted

A. D. Toth

Atlantic Richfield Hanford Company

M. H. Campbell

J. B. Fecht

W. M. Harty

R. E. Isaacson

H. H. Hopkins

L. M. Knights

W. P. McCue

H. P. Shaw

R. J. Sloat

P. W. Smith

R. E. Smith

R. E. Tomlins on

J. H. Warren

L. L. Zahn

File Copy

Battelle Memorial Institute

Douglas United Nuclear, Inc.

T. W. Ambrose

DUN File

$\underline{\text { Battelle-Northwest }}$

G. J. Alkire

J. M. Atwood

A. G. Blasewitz (2)

W. R. Bond

D. W. Brown

R. E. Burns

C. R. Cooley

E. A. Coppinger

D. R. deHalas

G. M. Dalen

V. L. Hammond

J. N. Hartley

M. M. Hendrickson

G. Jansen

J. D. Kaser

V. P. Kelly/T. J. Owen

H. A. Kornberg 
Battelle Northwest Contd

J. L. MeElroy

J.D. Moore

B.W. Mercer

J. E. Mendel

R. L. Moore

F. L. Mourich

H. M. Parker

D. W. Pearce

A. M. Platt,

K. J. Schneider (40)

$M$ 。 R. Sohwab

A. J. Shuckrow

R. J。 Thompson

C.J.Touhill

$\mathrm{H}$.H. Van Tuyl

E. E。 Voiland

W. K. Winegardner

N.G.Wittenbrock

Technical Information Files (5)

Technical Publications (2) 
